\title{
Pentacyclic Triterpenoids with Nitrogen-Containing Heterocyclic Moiety, Privileged Hybrids in Anticancer Drug Discovery
}

\author{
Vuyolwethu Khwaza, Sithenkosi Mlala, Opeoluwa O. Oyedeji (1) and Blessing A. Aderibigbe*
}

Department of Chemistry, University of Fort Hare, Alice Campus, Alice 5700, Eastern Cape, South Africa; vkhwaza@ufh.ac.za (V.K.); smlala@ufh.ac.za (S.M.); ooyedeji@ufh.ac.za (O.O.O.)

* Correspondence: blessingaderibigbe@gmail.com; Tel.: +27-4060-22-266

Citation: Khwaza, V.; Mlala, S.; Oyedeji, O.O.; Aderibigbe, B.A. Pentacyclic Triterpenoids with Nitrogen-Containing Heterocyclic Moiety, Privileged Hybrids in Anticancer Drug Discovery. Molecules 2021, 26, 2401. https://dx.doi.org/ 10.3390/molecules26092401

Academic Editors: György Szöllösi and Eva Frank

Received: 14 November 2020

Accepted: 29 November 2020

Published: 21 April 2021

Publisher's Note: MDPI stays neutral with regard to jurisdictional claims in published maps and institutional affiliations.

Copyright: () 2020 by the authors. Licensee MDPI, Basel, Switzerland. This article is an open access article distributed under the terms and conditions of the Creative Commons Attribution (CC BY) license (https: / / creativecommons.org/ licenses/by/4.0/).

\begin{abstract}
Pentacyclic triterpenoids are well-known phytochemicals with various biological activities commonly found in plants as secondary metabolites. The wide range of biological activities exhibited by triterpenoids has made them the most valuable sources of pharmacological agents. A number of novel triterpenoid derivatives with many skeletal modifications have been developed. The most important modifications are the formation of analogues or derivatives with nitrogencontaining heterocyclic scaffolds. The derivatives with nitrogen-containing heterocyclic compounds are among the most promising candidate for the development of novel therapeutic drugs. About $75 \%$ of FDA-approved drugs are nitrogen-containing heterocyclic moieties. The unique properties of heterocyclic compounds have encouraged many researchers to develop new triterpenoid analogous with pharmacological activities. In this review, we discuss recent advances of nitrogen-containing heterocyclic triterpenoids as potential therapeutic agents. This comprehensive review will assist medicinal chemists to understand new strategies that can result in the development of compounds with potential therapeutic efficacy.
\end{abstract}

Keywords: pentacyclic triterpenoids; $N$-heterocycles; hybrids; derivatives; anticancer; oleanolic acid

\section{Introduction}

Plants are considered common alternative for the treatment of cancer in most countries, and over 3000 plant species worldwide have anticancer properties [1,2] Plant-derived natural compounds have attracted the attention of many researchers due to their wide range of biological activities with various target sites and less toxic effects to normal cells [3]. Pentacyclic triterpenoids (PTs) are the most significant and well-studied phytochemicals. PTs have been screened for biological activities, and most of them displayed promising in vitro and in vivo potency [4]. A number of PTs and their derivatives are known to exhibit a wide range of biological activities such as anticancer [5-7], anti-HIV [8-10], anti-inflammatory [11,12], antimalarial [13], hepatoprotective [14,15], antimicrobial [16,17] antioxidant [18,19] and antidiabetic activities [20]. Currently, there is an increase in the number of patents being issued to protect new PTs with potential therapeutic effects, especially anticancer and antiviral [21-24]. Although PTs have such interesting biological properties, several disadvantages (e.g., low water solubility, selectivity, poor bioavailability, and short half-life) that hinder their potential therapeutic application in clinical use have been reported. Currently, the pharmacokinetic profile of PTs has not been thoroughly characterized, although numerous in vivo studies have been reported [25]. A vast number of studies have been performed to improve their pharmacological activities by introducing heterocyclic scaffolds into the PT's structure [26]. On the other hand, PTs can be a potential lead for the development of novel drugs. As a result, their structural modification has been reported as a promising strategy to enhance their pharmacological activity [27]. Among these PTs, derivatives with nitrogen-containing heterocyclic scaffolds play a major 
important role. Nitrogen-containing heterocyclic compounds are the most frequently used therapeutic agents. Firstly, these derivatives are usually more stable with good bioavailability. Additionally, heterocyclic derivatives have significant absorption bands upon UV light irradiation, which simplifies their detection in many in vivo studies and subsequent clinical testing; it helps to define the impurity profile in drug manufacture. Heterocyclic derivatives are easily prepared in selectively labeled form due to the good availability of building blocks in an isotopic form $\left({ }^{15} \mathrm{~N},{ }^{33} \mathrm{~S}\right.$, etc.). The above-mentioned advantages of heterocyclic derivatives give them great potential for use in pharmaceutical practice. These compounds have been used to develop various organic synthetic procedures and have a wide range of therapeutic applications [28,29]. Nowadays, triterpenoids with nitrogen-containing heterocyclic scaffolds have been extensively studied for their potential anticancer activities. In this review, we discuss synthesized triterpenoid hybrid compounds with fused nitrogen-containing heterocyclic ring(s) such as Triazole, Pyrazole, Indole, Piperazine, and Aminoquinolines with potential anticancer activity.

\section{Anticancer Activity of Pentacyclic Triterpenoids}

The morbidity and mortality rates caused by cancer are rapidly increasing globally. According to the 2018 statistics reported by the World Health Organisation (WHO), about 18.1 million cases of cancer were recorded, and 9.6 million cancer-related deaths. This means 1 in 6 deaths worldwide is due to cancer [30]. The use of chemotherapeutic agents in cancer treatment is always associated with side effects affecting organs and systems in the human body [31]. Many factors are responsible for the high rate of cancer, including age, population growth, lifestyle, etc. [32]. Cancer is known as the abnormal proliferation of cells, which can later invade different body parts. The currently used strategies for cancer treatment are chemotherapy, hormone therapy, and a combination of surgery and radiotherapy. However, some of the limitations associated with the conventional drugs used for the treatment of cancer are the unselective targeting of cells, multi-drug resistance, relapse of cancer, and poor outcomes [33]. The search for suitable and easily accessible treatment(s) for cancer, scientists and researchers around the world have turned their attention to natural products, phytochemicals, and their derivatives due to their therapeutic effects in the treatment of various diseases. Over $75-80 \%$ of the world's population consume medicinal plants for their health care [34]. More than $40 \%$ of conventional drugs originate from active natural products [35]. PTs are at the forefront of phytochemicals with anticancer activities as they act as a modulator of various molecular targets in multiple signaling pathways. Triterpenoids are functionalized triterpenes, which can be synthesized from plants through cyclization of squalene intermediate with six isoprene units [36]. From a biological viewpoint, most of the important triterpenoid structures are ursane, oleanane, and lupane triterpenoids (Figure 1) [37]. Many studies on PTs revealed their cytotoxicity on a variety of tumor growth cells without showing any lethality on normal cells [20]. Some of the synthetic triterpenoid derivatives, namely 2-cyano-3,12-dioxooleana-1,9(11)-dien-28-oic acid (CDDO) and its C-28 methyl ester (CDDO-Me), are already in Phase I clinical trials in cancer patients $[25,38]$. Betulinic acid derivative called bevirimat exhibited a significant and clinically relevant reduction of the viral load in ART-experienced and naive patients [39]. However, other clinical trials of bevirimat also revealed a high baseline drug resistance attributed to naturally occurring polymorphisms in HIV-1 Gag [40]. In terms of anticancer activity, PTs promote the cell apoptosis, which is one of the most significant mechanisms to suppress tumor. For example, PTs can trigger apoptosis by Interfering with the mitochondrial function of tumor cells [41]. In addition, they can also induce apoptosis by up-regulating p53 and caspase-3 gene expressions and suppressing the NF- $\mathrm{kB}$ mediated activation of Bcl-2 in B16F-10 melanoma cells [42]. PTs can enhance tumor necrosis factor (TNF)-related apoptosis-inducing ligand (TRAIL) [43,44]. Other studies revealed that PTs inhibit the activation of STAT3 induced by interleukin-6 in DLD-1 colon cancer cells [45]. 

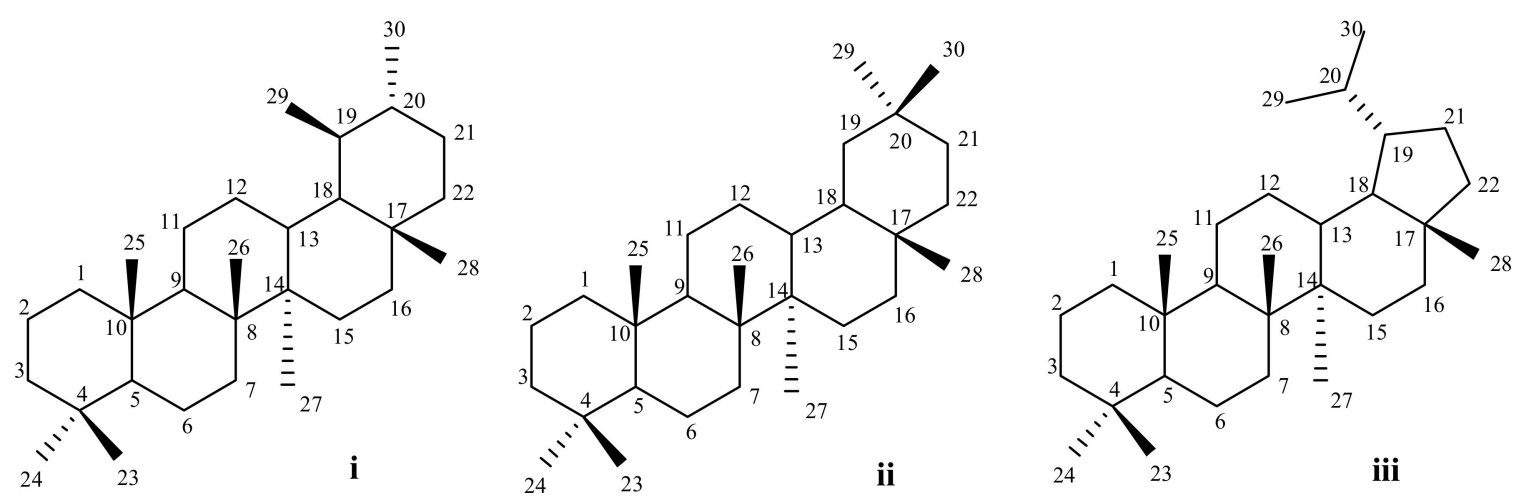

Figure 1. Three different types of triterpenoid skeletons described in this review with carbon numbering: ursane (i), oleanane (ii), and lupane (iii).

\section{Triazole}

1,2,3-triazole derivatives has attracted much attention due to their interesting pharmacological activities such as anticancer [46-48], antimalarial [49], antibacterial [50,51], antifungal [52-54], anti-inflammatory [55], and antiviral activities [56,57]. In addition, some 1,2,3-triazole-based derivatives are under clinical evaluation for their potential use in cancer treatment [58]. Hybrid molecules can overcome drug resistance and reduce side effects since hybrids containing two or more different compounds can also display multiple modes of action. Hybrid molecules containing 1,2,3-triazole moiety and other anticancer agents are potential anticancer agents that can display low toxicity and high therapeutic effects against drug-resistant cancers. In recent years, PTs such as betulinic, oleanolic, and ursolic acid were found to possess potent anticancer activity with various molecular targets. The attachment of these phytochemicals with 1,2,3-triazole moiety is a promising approach to developing novel anticancer agents that are effective against drug-resistant cancers due to their distinct mechanisms.

\subsection{Anticancer Effects of Betulinic Acid-Based 1,2,3-Triazole Molecules}

A small library of novel amide-triazole-linked triterpenoid-AZT conjugates were prepared by Tuyet Anh Dang Thi and his group [59]. The anticancer effects of these hybrid compounds were evaluated against KB and Hep-G2 tumor cells. The most effective compounds that emerged from the in vitro cytotoxicity studies were $(5 \mathbf{a}, 5 \mathbf{b}$, and $\mathbf{6}$ (Figure 2, Table 1)). With similar work, these authors also synthesized 12 novel estertriazole-linked triterpenoid-AZT conjugates, and three compounds $(7,8$, and 9 (Figure 2, Table 1)) showed the most potent cytotoxicity activity against tumor cells (KB and HepG2) [60]. Majeed et al. [61] carried out the chemical transformation studies on betulinic acid through a concise synthesis of betulinic acid-based-1,2,3-triazole derivatives via click chemistry approach at $\mathrm{C}-3$ position. Their cytotoxic effect was investigated against nine human tumor cell lines, namely THP-1, HL-60, DU-145, PC-3, HEP-2, MCF-7, A-549, SF-295, and HCT-15. Most of the derivatives exhibited higher cytotoxic profiles than the parent molecule. Most of the derivatives exhibited higher cytotoxic profiles than the parent molecule. In total, two compounds (i.e., 10 and 11 (Figure 2, Table 1)) showed impressive $\mathrm{IC}_{50}$ values ( 2.5 and $3.5 \mu \mathrm{M}$, respectively) against leukemia cell line HL-60 (5-7-fold higher potency than betulinic acid). The two compounds induced apoptosis, inhibited cell migration, and colony formation, mitochondrial membrane disruption followed by DNA fragmentation [61]. Khan et al. (2016) [62] synthesized a series of 1,2,3 triazole derivatives linked at C-3 and C-28 of betulinic acid using click chemistry approach. All the synthetic compounds were screened for their in vitro cytotoxicity against four human cancer cells, namely HL-60, PC-3, A549, and MiaPaCa-2. Among these derivatives, $\{1 \mathrm{~N}$ (4-fluoro phenyl)-1H-1, 2, 3-triazol-4-yl\} methyloxy betulinic ester (12) (Figure 2, Table 1) displayed better potency than the parent compound betulinic acid with $\mathrm{IC}_{50}$ values ranging 
from 5 to $7 \mu \mathrm{M}$. It disrupted the mitochondrial membrane potential, rendered Bcl-2 cleavage, Bax translocation, and decreased Bcl-2/Bax ratio. These events were accompanied by activation of caspases 9, 3, which cleaved the PARP-1. It also induced caspase-8, which is involved in the extrinsic apoptotic pathway. Therefore, it induces apoptosis through intrinsic and extrinsic pathways in human leukemia HL-60 cells [62]. Suman et al. (2017) [63] used click chemistry and Baylis-Hillman reaction protocols to synthesize betulinic acid-triazole derivatives. These derivatives were tested for their cytotoxic effects in human pancreatic cancer (MIA PaCa-2) and murine breast cancer (4T1) cell lines. Based on the in vitro assays, two compounds (13 and 14) (Figure 3, Table 1) were identified as lead compounds with $\mathrm{IC}_{50}$ values of $2.38 \pm 0.45 \mu \mathrm{M}(4 \mathrm{~T} 1), 1.36 \pm 0.21 \mu \mathrm{M}$ (MIA PaCa-2) and $2.62 \pm 0.24 \mu \mathrm{M}$ (4T1), $1.64 \pm 0.20 \mu \mathrm{M}$ (MIA PaCa-2) [63]. A series of triazole-linked betulin and betulinic acid analogs were synthesized via click chemistry at C-30 position by Shi and colleagues [64]. Their in vitro antitumor activities in leukemia cell line (HL-60) was studied. The in vitro cytotoxic analysis indicated that most of betulinic acid-based triazoles had higher cytotoxic activity compared to betulinic acid. In all the synthesized compounds, compound (15) (Figure 3, Table 1) showed the best $\mathrm{IC}_{50}$ value $(1.3 \mu \mathrm{M})$ against leukemia cell-line HL-60, which had an eight- to nine-fold higher potency than betulinic acid [64]. Sidova et al. [65] used Huisgen 1,3-cycloaddition protocol to synthesize betulinic acid substituted triazole conjugates and evaluated them for in vitro cytotoxic activities against eight human cancer cell lines and two noncancer cell lines. Conjugates of $3 \beta-O$-acetylbetulinic acid were the most active compounds, and among them, compound $\mathbf{1 6}$ with triazole substituted by benzaldehyde was found to be the most active with an $\mathrm{IC}_{50}$ of $3.3 \mu \mathrm{M}$ and therapeutic index (TI) of 9.1. The compound inhibited DNA and RNA synthesis and caused block in G0/G1 cell cycle phase which is highly similar to reference drug actinomycin D [65]. Chakraborty et al. (2015) [66] applied the azide-alkyne "click reaction" to synthesis a panel of novel betulinic acid analogues containing a triazole unit at C-3 attached through a linker. These analogues were screened for their anticancer activity against various cancer cell lines and normal human PBMC using MTT assays. Compound 17 (Figure 2, Table 1) showed the most potent inhibitory effect against cell line HT-29 with an $\mathrm{IC}_{50}$ value of $14.9 \mu \mathrm{M}$. They further investigated its mode of action and it exhibited much higher cytotoxicity than the standard drug, 5-fluorouracil but showed negligible cytotoxicity towards normal PBMC. The elevated level of ROS generation, activation of caspase 3 and caspase 9, DNA fragmentation, higher expression of Bax and Bad, lower expression of $\mathrm{Bcl} 2$ and $\mathrm{Bcl}-\mathrm{xl}$, and increased level of Bax/Bcl-xl ratio identified 17 (Figure 2, Table 1) as a promising inducer of apoptosis that follows a mitochondria-dependent pathway. Biophysical studies indicated that compound $\mathbf{1 7}$ (Figure 2, Table 1) acts as a minor groove binder to the DNA [66]. Novel triazole hybrids of betulin were synthesized using the 1,3-dipolar cycloaddition reaction between the alkyne derivatives of betulin and organic azides. In this study, bistriazole (compound 18) (Figure 2, Table 1) was identified as a potent compound with an $\mathrm{IC}_{50}$ value of $0.05 \mu \mathrm{M}$ against T47D (human ductal carcinoma cells) with 500-fold higher potency than cisplatin [67]. 

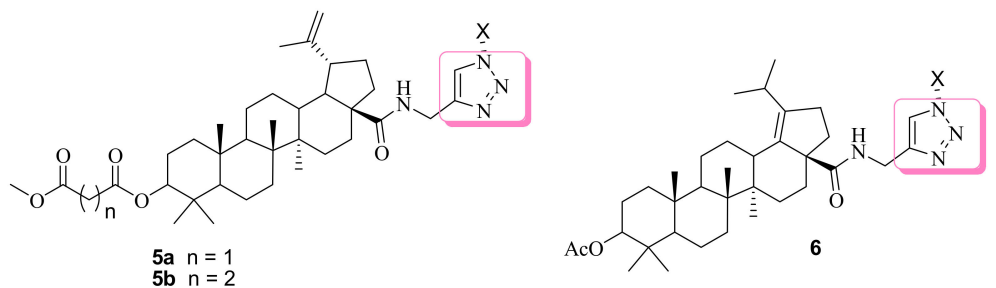

$\begin{array}{ll}5 \text { a } & n=1 \\ 5 b & n=2\end{array}$
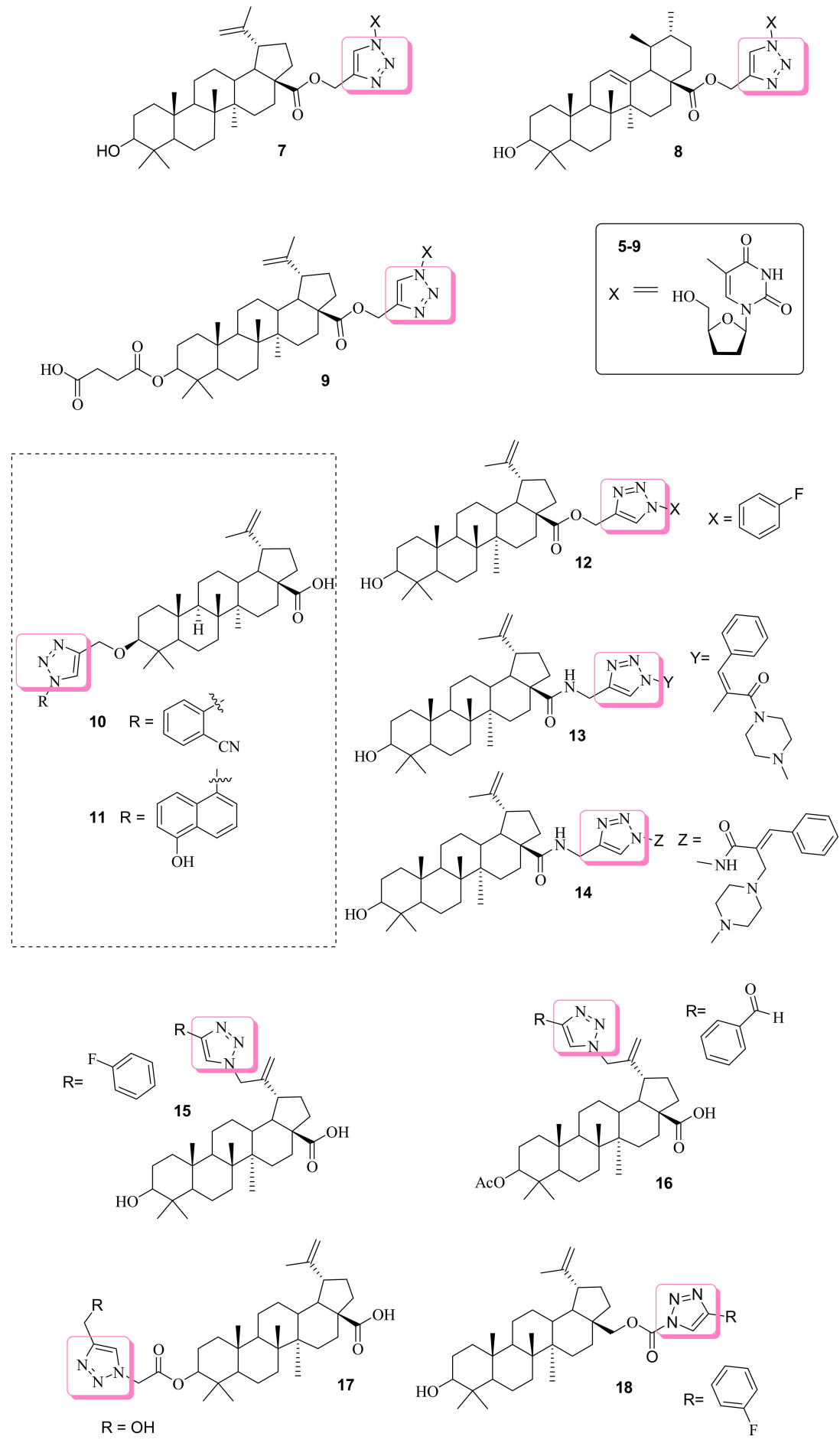

Figure 2. Betulinic acid-based 1,2,3-triazole analogues. 

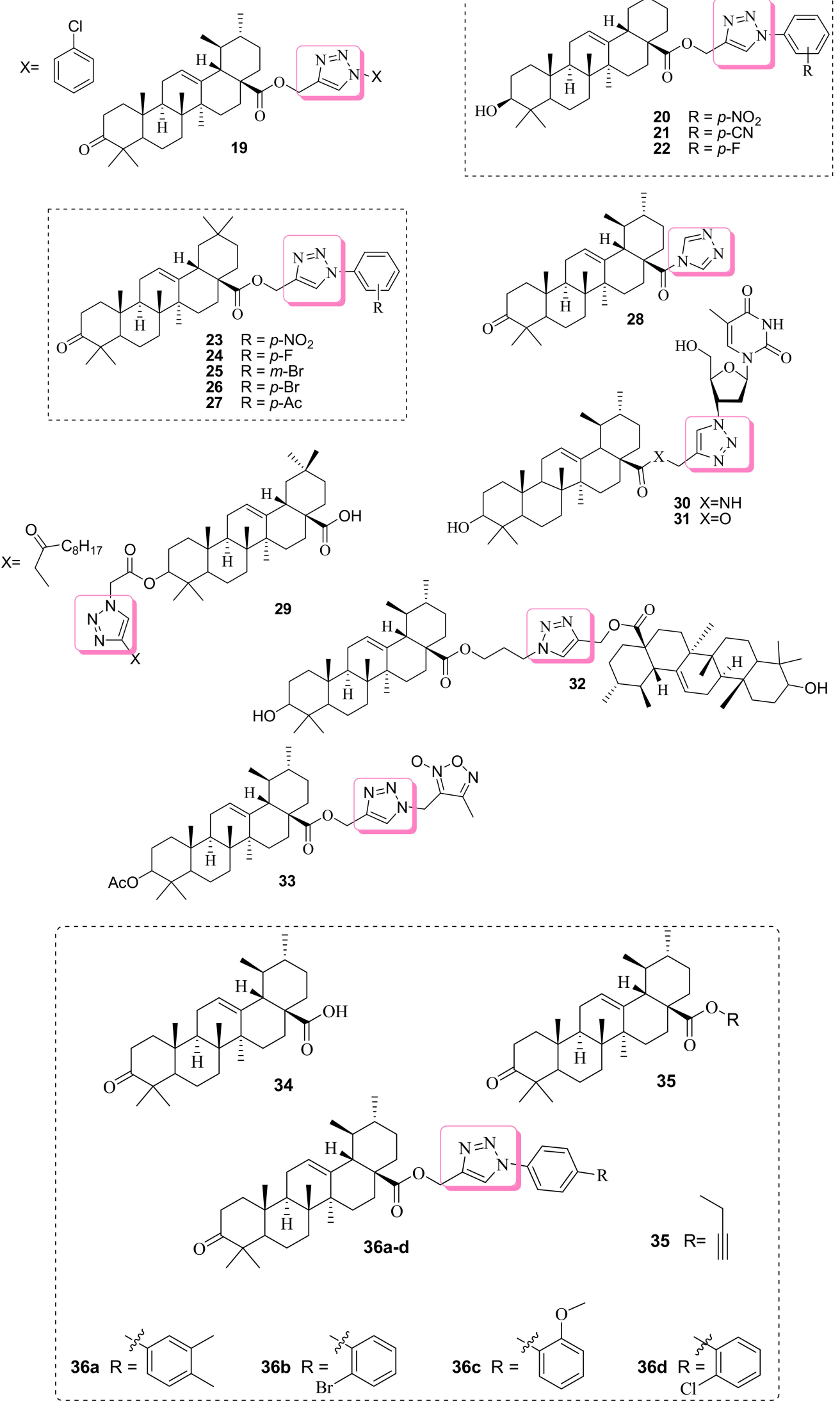

Figure 3. Ursolic acid and oleanolic acid-based triazole hybrid compounds. 


\subsection{Anticancer Effects of Ursolic/oleanolic Acid-Based 1,2,3-Triazole Molecules}

Zhu et al. (2015) [68] investigated the anticancer effect of ursolic acid chlorophenyl triazole (UACT) (19) and 5-fluorouracil (5-FU) against human lung cancer cell lines (H209, 87-5 and Lu135) (Figure 3, Table 1). The results revealed a synergistic effect of the sequential treatment with UACT and 5-FU combination on cytotoxic activities, NF-kB protein activation, repression of TNF-induced NF-kB-dependent reporter gene expression, and TNF-induced COX-2, MMP-9, and Cyclin D1 activation in H209 cells. The synergism in apoptotic cell death was observed in H209, H69, 87-5, and Lu135 cells. The synergistic effect of UACT and 5-FU was observed at a concentration of $50 \mathrm{nM}$ of UACT and $20 \mu \mathrm{M}$ of 5-FU. Wei et al. [69] designed and synthesized a library of novel oleanolic acid coupled 1,2,3-triazole derivatives using a $\mathrm{Cu}(\mathrm{I})$ catalyzed Huisgen 1,3-dipolar cycloaddition reaction. The antiproliferative analysis revealed some of the synthetic compounds excellent anticancer activity on human tumor cell lines such as HeLa, HepG2, HCT116, A375-S2, and HT1080. Among all the derivatives, compounds 20, 21, and 22, with $p-\mathrm{NO}_{2}, p-\mathrm{CN}$, and $p$-F substitutions at an aromatic ring (Figure 3, Table 1) possessed the best inhibitory activity against HT1080 cells. The pharmacology experiments showed that compound $\mathbf{2 0}$ significantly induced HT1080 cell apoptosis [69]. In a similar study, Fengran et al. [70] further synthesized 15 novel 3-oxo-oleanolic acid coupled 1,2,3-triazole derivatives. Compounds 23-27 (Figure 3, Table 1) displayed the best potent activity and selectivity against A375-S2 and HT1080 cell lines with $\mathrm{IC}_{50}$ values ranging from 1.69-2.82 $\mu \mathrm{M}$. In this study, it was evident that the 3-oxo OA derivatives displayed better anticancer activity compared to OA derivatives [70].

Leal and colleagues [71] developed a series of novel $\mathrm{N}$-acylimidazoles and $\mathrm{N}$-alkylimidazoles ursolic acid analogues bearing imidazole or triazole in different positions of the ursane skeleton and evaluated the anti-proliferative effect in pancreatic cancer cells (AsPC-1). The tested compounds exhibited improved the antiproliferative activity against AsPC-1 cells than the parent compound, ursolic acid. Compound 28 (Figure 3, Table 1) was seven-fold more potent than ursolic acid with an $\mathrm{IC}_{50}$ value of $1.9 \mu \mathrm{M}$. Compound 28 also indicated the induction of p21 ${ }^{\text {waf1 }}$, p53, and NOXA, which led to cell cycle arrest and AsPC- 1 apoptosis [71]. A total of 18 derivatives of oleanolic acid were prepared and investigated for their in vitro cytotoxic activity by Pertino et al. [72], and compound 29 (Figure 3, Table 1) showed better activity with an $\mathrm{IC}_{50}$ value of $8.9 \mu \mathrm{M}$ against gastric epithelial adenocarcinoma cells (AGS cells). Ursolic acid derivatives containing either an amide-triazole-AZT linkage (as in 30) or an ester-triazole-AZT linkage (as in 31) (Figure 4, Table 1) showed moderate cytotoxic activity [59]. High cytotoxicity was observed for ursolic acid derivative, 32 (Figure 3, Table 1) modified at position C-28. This compound $\mathrm{GI}_{50}$ values was $1.4 \mu \mathrm{M}$ against the human breast tumor cell lines (MDA-MB-231) [73,74]. Ursolic acid derivatives (33) (Figure 3, Table 1) containing heterocyclic fragments such as 1,2,3-triazole and 3-(methyl)-4-methyl-1,2,5-oxadiazole-2-oxide linked at position C-28 displayed the best cytotoxic activity against MCF-7 cells with $\mathrm{IC}_{50}$ value of $1.55 \pm 0.08 \mu \mathrm{M}$ comparable to doxorubicin. The molecular docking studies indicated that the most likely cytotoxic mechanism of action is the affinity of hybrid 33 to Mdm2 binding sites [75].

A number of ursolic acid-1-phenyl-1H-[1-3]triazol-4-ylmethylester congeners were designed and synthesized by Rashid et al. (2013) [76] in an attempt to develop potent antitumor agents. To synthesize these congeners, UA was subjected to oxidation using Jones reagent at $0{ }^{\circ} \mathrm{C}$ that resulted in the formation of $\mathrm{C}-3$ oxidized derivative (34)(Figure 3) in almost quantitative yield. Propargylation of the carboxylic group at $\mathrm{C}-28$ was tried with different bases, including $\mathrm{NaHCO}_{3}, \mathrm{Cs}_{2} \mathrm{CO}_{3}$, pyridine, $\mathrm{Et}_{3} \mathrm{~N}$, and $\mathrm{DBU} . \mathrm{Cs}_{2} \mathrm{CO}_{3}$ condition in dry THF delivered the well-poised alkyne derivative 35 (Figure 3) in excellent yield. On the other hand, aromatic azides were prepared from their respective anilines by diazotization with sodium nitrite in acidic conditions followed by displacement with sodium azide in good to excellent yield. 1,3-dipolar cycloaddition reaction of $\mathbf{3 5}$ with aromatic azides in the presence of $\mathrm{CuSO}_{4} \cdot 5 \mathrm{H}_{2} \mathrm{O}$ and sodium ascorbate in t-BuOH: $\mathrm{H}_{2} \mathrm{O}$ (2:1) resulted in the formation of 1,4-substituted-triazolyl derivatives 36a-d (Figure 3) in excellent yields. All the compounds were evaluated for anticancer activity against a panel 
of four human cancer cell lines, such as A-549 (lung), MCF-7 (breast), HCT-116 (colon), THP-1 (leukemia), and a normal human epithelial cell line (FR-2) using sulforhodamine-B assay. The pharmacological results showed that most of the compounds displayed a high level of antitumor activities against the tested cancer cell lines compared with ursolic acid. Compounds 36a-d (Table 1) were found to be the most potent compounds.

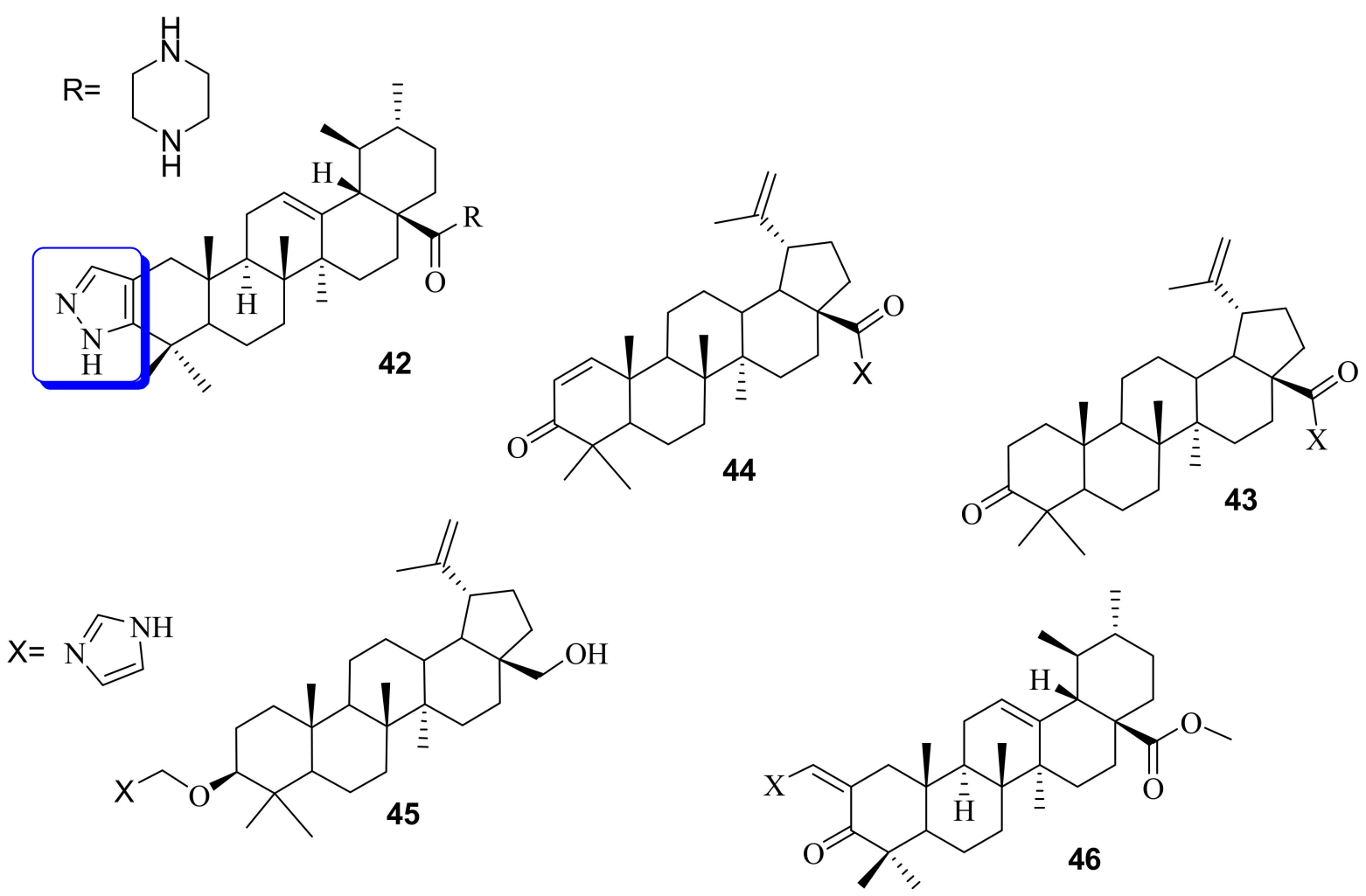

Figure 4. Ursolic acid and betulinic acid-base pyrazole derivatives. 
Table 1. Mechanism and cytotoxicity of pentacyclic triterpenoids (PTs)-based triazole scaffolds on different cancer cells.

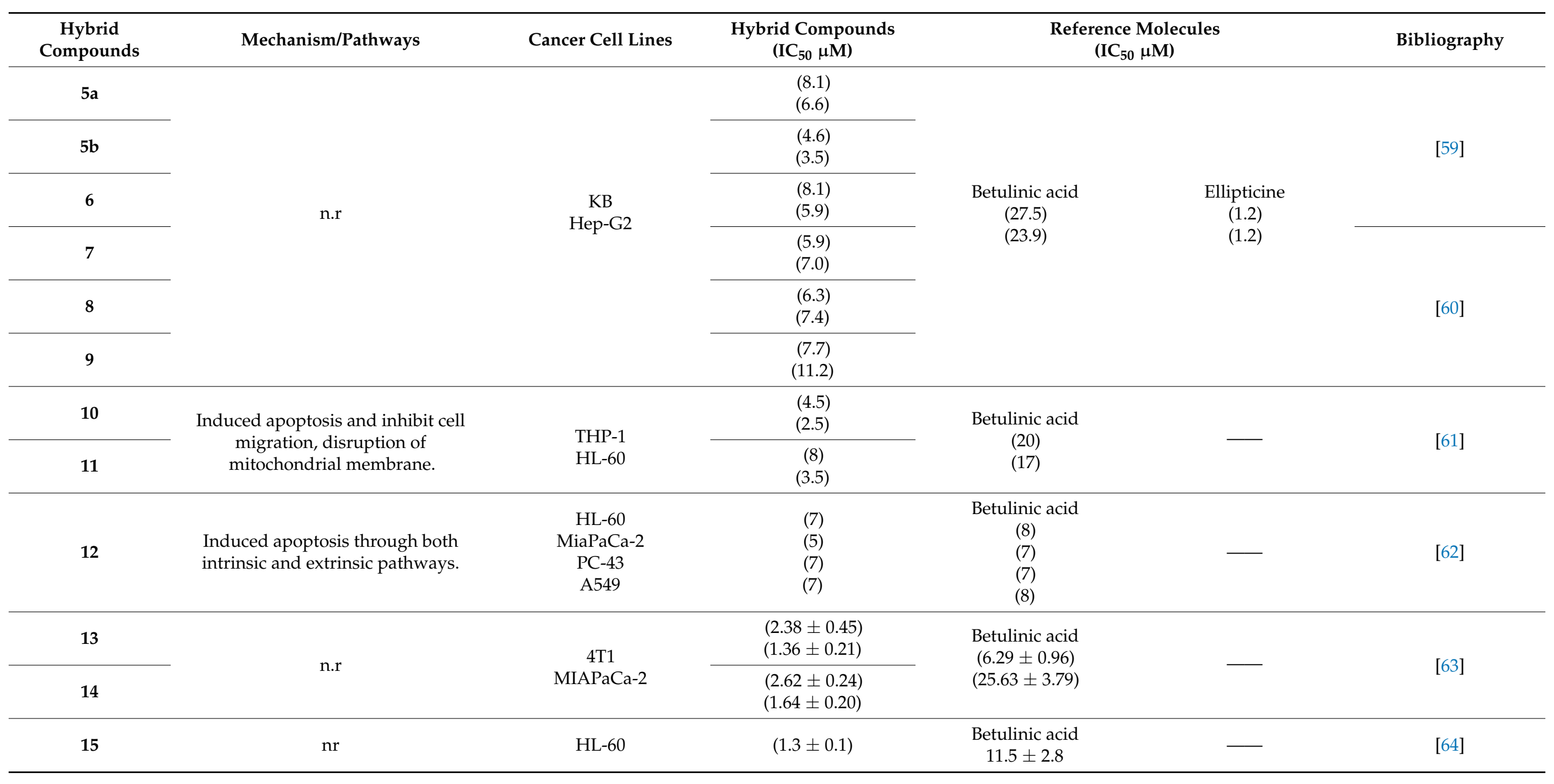


Table 1. Cont.

\begin{tabular}{|c|c|c|c|c|c|c|}
\hline $\begin{array}{c}\text { Hybrid } \\
\text { Compounds }\end{array}$ & Mechanism/Pathways & Cancer Cell Lines & $\begin{array}{l}\text { Hybrid Compounds } \\
\quad\left(\mathrm{IC}_{50} \mu \mathrm{M}\right)\end{array}$ & \multicolumn{2}{|c|}{$\begin{array}{l}\text { Reference Molecules } \\
\quad\left(\mathrm{IC}_{50} \mu \mathrm{M}\right)\end{array}$} & Bibliography \\
\hline 16 & $\begin{array}{l}\text { Inhibit DNA and RNA, cause block in } \\
\text { G0/G1 cell cycle phase similar to } \\
\text { actinomycin D. }\end{array}$ & $\begin{array}{c}\text { CCRF-CEM } \\
\text { CEM-DNR } \\
\text { K562 } \\
\text { K562-TAX } \\
\text { A549 } \\
\text { HCT116 } \\
\text { HCT116p53-/- } \\
\text { U2OS }\end{array}$ & $\begin{array}{c}(3.3) \\
(4.0) \\
(3.6) \\
(3.9) \\
(14.8) \\
(6.4) \\
(9.5) \\
(12.8)\end{array}$ & $\begin{array}{l}\text { Betulinic acid } \\
(45.5) \\
(45.4) \\
(40.0) \\
(43.1) \\
(43.4) \\
(38.0) \\
(50.0) \\
(50.0) \\
\end{array}$ & - & [65] \\
\hline 17 & $\begin{array}{l}\text { Induce apoptosis, acts as a minor } \\
\text { groove binder to the DNA }\end{array}$ & HT29 & $(14.9 \pm 1.3)$ & $\begin{array}{l}\text { Betulinic acid } \\
(14.9 \pm 1.3)\end{array}$ & 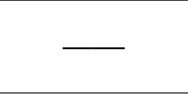 & [66] \\
\hline 18 & n.r & $\begin{array}{l}\text { T47D2 } \\
\text { MCF-7 } \\
\text { SNB-19 }\end{array}$ & $\begin{array}{l}(0.05 \pm 0.01) \\
(0.09 \pm 0.01) \\
(0.08 \pm 0.01)\end{array}$ & $\begin{array}{l}\text { Betulinic acid } \\
\quad(\text { neg) } \\
(17.7 \pm 1.2) \\
\quad(\text { neg })\end{array}$ & $\begin{array}{l}\text { Cisplatin } \\
(4.9 \pm 1.1) \\
(5.5 \pm 1.0) \\
(2.3 \pm 0.05)\end{array}$ & [67] \\
\hline 19 & $\begin{array}{l}\text { Activate NF-kB protein, repression of } \\
\text { TNF-induced NF-kB-dependent } \\
\text { reporter gene expression, and } \\
\text { TNF-induced COX-2, MMP-9 and } \\
\text { Cyclin D1 activation }\end{array}$ & n.r & n.r & n.r & n.r & [68] \\
\hline 20 & Apoptosis inducer in HT1080 cells & $\begin{array}{l}\text { HeLa } \\
\text { HepG2 } \\
\text { HCT116 } \\
\text { A375-S2 } \\
\text { HT1080 }\end{array}$ & $\begin{array}{l}(10.85) \\
(24.15) \\
(12.28) \\
(4.97) \\
(3.51)\end{array}$ & $\begin{array}{l}\text { Oleanolic acid } \\
\qquad \begin{array}{l}(200) \\
(200) \\
(200) \\
(200) \\
(200)\end{array}\end{array}$ & $\begin{array}{l}5-\mathrm{Fu} \\
(26.18) \\
(67.64) \\
(35.16) \\
(90.74) \\
(25.46)\end{array}$ & [69] \\
\hline
\end{tabular}


Table 1. Cont.

\begin{tabular}{|c|c|c|c|c|c|c|}
\hline $\begin{array}{c}\text { Hybrid } \\
\text { Compounds }\end{array}$ & Mechanism/Pathways & Cancer Cell Lines & $\begin{array}{l}\text { Hybrid Compounds } \\
\quad\left(\mathrm{IC}_{50} \mu \mathrm{M}\right)\end{array}$ & \multicolumn{2}{|c|}{$\begin{array}{l}\text { Reference Molecules } \\
\left(\mathrm{IC}_{50} \mu \mathrm{M}\right)\end{array}$} & \multirow[t]{2}{*}{ Bibliography } \\
\hline 23 & \multirow{4}{*}{ n.r } & \multirow{4}{*}{$\begin{array}{l}\text { A375-S2 } \\
\text { HT1080 }\end{array}$} & $(1.69 \pm 0.26)$ & & & \\
\hline 24 & & & $\begin{array}{c}(36.54 \pm 0.39) \\
(1.86 \pm 0.17)\end{array}$ & & & \multirow{3}{*}[70]{} \\
\hline 25 & & & $\begin{array}{c}(13.98 \pm 0.78) \\
(1.73 \pm 0.45)\end{array}$ & $\begin{array}{l}(59.57 \pm 0.17) \\
(35.18 \pm 0.44)\end{array}$ & $\begin{array}{l}(59.57 \pm 0.17) \\
(35.18 \pm 0.44)\end{array}$ & \\
\hline 27 & & & $\begin{array}{l}(4.76 \pm 0.11) \\
(1.84 \pm 0.16)\end{array}$ & & & \\
\hline 28 & $\begin{array}{c}\text { Induction of p21 waf1, p53 and NOXA } \\
\text { which leads to cell cycle arrest and } \\
\text { AsPC-1 apoptosis }\end{array}$ & AsPC-1 & $(1.9 \pm 0.02)$ & $\begin{array}{l}\text { Ursolic acid } \\
(15.2 \pm 0.1)\end{array}$ & - & {$[71]$} \\
\hline 29 & $\begin{array}{l}\text { Inhibits proliferation of Gastric } \\
\text { epithelial adenocarcinoma(AGS) }\end{array}$ & $\begin{array}{c}\text { MRC-5 } \\
\text { AGS } \\
\text { SK-MES-1 } \\
\text { J82 } \\
\text { HL-60 }\end{array}$ & $\begin{array}{c}(100) \\
(8.9 \pm 0.4) \\
(50.4 \pm 3.5) \\
(35.4 \pm 2.8) \\
(35.8 \pm 4.1)\end{array}$ & - & $\begin{array}{c}\text { Etoposide } \\
(0.33 \pm 0.02) \\
(0.58 \pm 0.02) \\
(1.83 \pm 0.09) \\
(3.49 \pm 0.16) \\
(2.23 \pm 0.09)\end{array}$ & {$[72]$} \\
\hline 33 & Affinity to Mdm2 binding sites & $\begin{array}{l}\text { MCF-7 } \\
\text { U-87 MG } \\
\text { A549 } \\
\text { HepG2 }\end{array}$ & $\begin{array}{l}(1.55 \pm 0.08) \\
(>100) \\
(>100) \\
(>100)\end{array}$ & $\begin{array}{c}\text { Ursolic acid } \\
(25.05 \pm 3.17) \\
(43.82 \pm 3.88) \\
(41.02 \pm 3.77) \\
(37.28 \pm 5.02)\end{array}$ & $\begin{array}{c}\text { Doxorubicin } \\
(4.51 \pm 1.12) \\
(2.05 \pm 0.22) \\
(6.17 \pm 1.17) \\
(10.02 \pm 1.67)\end{array}$ & {$[75]$} \\
\hline
\end{tabular}


Table 1. Cont.

\begin{tabular}{|c|c|c|c|c|c|}
\hline $\begin{array}{c}\text { Hybrid } \\
\text { Compounds }\end{array}$ & Mechanism/Pathways & Cancer Cell Lines & $\begin{array}{l}\text { Hybrid Compounds } \\
\quad\left(\mathrm{IC}_{50} \mu \mathrm{M}\right)\end{array}$ & $\begin{array}{l}\text { Reference Molecules } \\
\quad\left(\mathrm{IC}_{50} \mu \mathrm{M}\right)\end{array}$ & Bibliography \\
\hline $36 a$ & & \multirow{4}{*}{$\begin{array}{c}\text { A-549 } \\
\text { MCF-7 } \\
\text { HCT-116 } \\
\text { THP-1 } \\
\text { FR-2 }\end{array}$} & $\begin{array}{c}(0.5 \pm 0.05) \\
(5.5 \pm 0.08) \\
(<0.1 \pm 0.09) \\
(0.9 \pm 0.02) \\
(10 \pm 0.04)\end{array}$ & \multirow{4}{*}{$\begin{array}{c}\text { Ursolic acid } \\
(33 \pm 0.03) \\
(37 \pm 0.07) \\
(42 \pm 0.08) \\
(9.1 \pm 0.07) \\
(31 \pm 0.08)\end{array}$} & \multirow{4}{*}{ [76] } \\
\hline $36 b$ & & & $\begin{array}{c}(2.9 \pm 0.05) \\
(<0.1 \pm 0.05) \\
(15 \pm 0.06) \\
(<0.1 \pm 0.03) \\
(69 \pm 0.05)\end{array}$ & & \\
\hline $36 c$ & & & $\begin{array}{c}(<0.1 \pm 0.001) \\
(<0.1 \pm 0.09) \\
(0.3 \pm 0.001) \\
(<0.1 \pm 0.001) \\
(>50 \pm 4.1)\end{array}$ & & \\
\hline $36 d$ & & & $\begin{array}{c}(0.15 \pm 0.01) \\
(<0.1 \pm 0.001) \\
(9.1 \pm 1.0) \\
(<0.1 \pm 0.001) \\
(>50 \pm 3.9)\end{array}$ & & \\
\hline
\end{tabular}




\section{Pyrazole}

Pyrazole, a five-membered heterocyclic ring, is the most studied compound among the azole family due to its interesting pharmacological properties such as antibacterial, anticancer, antioxidant, antifungal, antidepressant, antituberculosis, anti-inflammatory, and antiviral activities [77-79]. The pyrazole ring is the best scaffold for synthesizing various pharmaceutical compounds with different therapeutic activities and good safety profiles [80]. Most of the synthesized pyrazole derivatives have been studied for their in vitro antiproliferative activities and in vivo antitumor activity, often resulting in promising lead scaffolds [81-85]. Recently, Bennani et al. also demonstrated that pyrazole derivatives possess high antiproliferative activity against tumors cells such as breast (MCF-7), lung (A-549), liver (HepG-2), and brain (HeLa) cell lines [86]. In a continuing interest in pyrazole-based derivatives, PTs with pyrazole rings have been reported.

\section{Anticancer Effects of Triterpenoid-Based Pyrole Molecules}

Sun et al. [87] synthesized pyrazole-fused ursolic acid derivative $\mathbf{4 1}$ (Scheme 1, Table 2) and evaluated their in vitro anticancer activities against tumor cells, such as cervical carcinoma (HeLa cells), hepatocellular carcinoma (HepG2 cells), fibrosarcoma (HT1080 cells), mammary adenocarcinoma (MCF-7 cells), and neuroblastoma (SK-N-MC cells). This compound induced apoptosis by hyperstimulation of macropinocytosis and caused the accumulation of vacuoles derived from macropinosomes based on transmission electron microscopy, time-lapse microscopy, and labelling with extracellular fluid phase tracers.

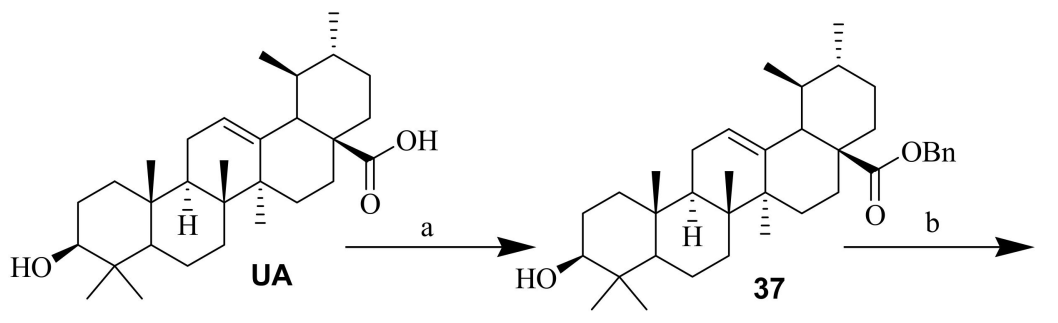<smiles>CCCOC(=O)C12CC[C@H](C)C(C)C1C1=CC[C@H]3C4(C)CCC(=O)C(C)(C)C4CC[C@]3(C)[C@]1(C)CC2</smiles>

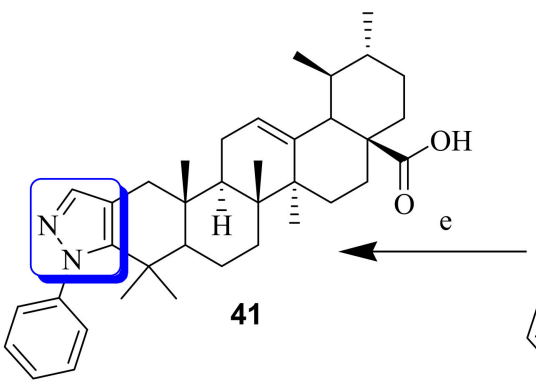

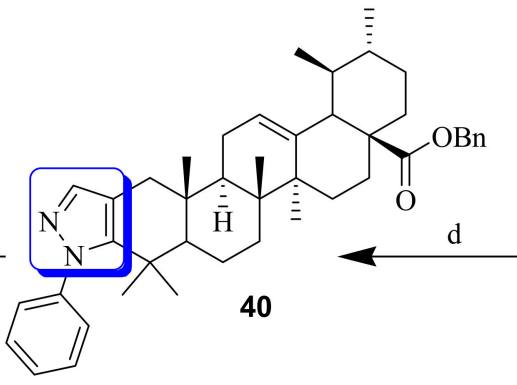<smiles>C[C@H]1CCC2(C(=O)OCc3ccccc3)CC[C@]3(C)C(=CCC4[C@@]5(C)CC(C=O)C(=O)C(C)(C)C5CC[C@]43C)C2[C@@H]1C</smiles>

Scheme 1. Reagents and conditions: (a) $\mathrm{BnBr}, \mathrm{K}_{2} \mathrm{CO}_{3}, \mathrm{DMF}, 60{ }^{\circ} \mathrm{C}, 92 \%$. (b) $\mathrm{PCC}, \mathrm{CH}_{2} \mathrm{Cl}_{2}, 0{ }^{\circ} \mathrm{C}$ to rt, $84 \%$. (c) $\mathrm{R}_{1} \mathrm{CO}_{2} \mathrm{Et}$ $\left(\mathrm{R}_{1}=\mathrm{H}, \mathrm{Me}\right), \mathrm{NaOMe}, \mathrm{THF}, \mathrm{rt}$; R1 CO2Et $\left(\mathrm{R}_{1}=\mathrm{CF}_{3}\right)$, t-BuOK, THF, rt, 70\%. (d) $\mathrm{R}_{2} \mathrm{NHNH}_{2} \cdot \mathrm{HCl}, \mathrm{EtOH}, \mathrm{rt}$. (e) $\mathrm{H} 2, \mathrm{Pd} / \mathrm{C}$, $\mathrm{MeOH}, \mathrm{rt}$.

$\mathrm{Li}$ and colleagues [88] synthesized novel ursolic acid derivative 42 (Figure 4, Table 2) with a nitrogen-containing heterocyclic scaffold and the privileged fragment at the C28 position by treating UA with acetic anhydride $\left(\mathrm{Ac}_{2} \mathrm{O}\right)$ in dry pyridine under the 4dimethylaminopyridine $\left.\left(\mathrm{CH}_{3}\right)_{2} \mathrm{NC}_{5} \mathrm{H}_{4} \mathrm{~N}\right)$ at room temperature for $2 \mathrm{~h}$. The 3-acetylated UA was treated with oxalyl chloride at room temperature for $3 \mathrm{~h}$ to produce an intermediary 28-acyl chloride. This compound was then mixed at room temperature for $2 \mathrm{~h}$ to synthesize compound 42. These authors investigated cell proliferation, apoptosis induction, and cell cycle in human breast cancer lines. The results indicated that $\mathbf{4 2}$ significantly increased the number of SUM149PT and HCC1937 cells lines in the $\mathrm{G}_{0} / \mathrm{G}_{1}$ phase in a dose-dependent 
manner. Compound 42 significantly induced apoptosis in breast cancer more than UA [88]. Chen et al. [89] also synthesized 42, which exhibited a remarkable growth of the inhibitory effect against HL-60 cells leukemia cells with an $\mathrm{IC}_{50}$ value of $0.91 \mu \mathrm{M}$, approximately 100-fold more potent than UA [89].

Table 2. Mechanism and cytotoxicity of PTs-based pyrazole scaffolds on different cancer cells.

\begin{tabular}{|c|c|c|c|c|c|c|}
\hline $\begin{array}{c}\text { Hybrid } \\
\text { Compounds }\end{array}$ & $\begin{array}{l}\text { Mechanism } \\
\text { /Pathways }\end{array}$ & $\begin{array}{c}\text { Cancer Cell } \\
\text { Lines }\end{array}$ & $\begin{array}{c}\text { Hybrid } \\
\text { Compounds } \\
\left(\mathrm{IC}_{50} \mu \mathrm{M}\right)\end{array}$ & $\begin{array}{r}\text { Reference } \\
\left(\text { IC }_{5}\right.\end{array}$ & $\begin{array}{l}\text { Iolecules } \\
\text { M) }\end{array}$ & Bibliography \\
\hline 41 & $\begin{array}{l}\text { Induced apoptosis by } \\
\text { hyperstimulation of } \\
\text { macropinocytosis }\end{array}$ & $\begin{array}{c}\text { Hela } \\
\text { HepG2 } \\
\text { HT1080 } \\
\text { MCF-7 } \\
\text { SK-N-MC }\end{array}$ & $\begin{array}{c}(18.63 \pm 2.34) \\
(27.87 \pm 2.98) \\
(26.7 \pm 0.07) \\
(25.25 \pm 0.07) \\
(28.63 \pm 1.03)\end{array}$ & $\begin{array}{c}\text { Ursolic acid } \\
(43.30 \pm 2.22) \\
(34.12 \pm 0.68) \\
(39.43 \pm 0.52) \\
(57.64 \pm 5.75) \\
(67.64 \pm 1.78)\end{array}$ & 一 & [87] \\
\hline 42 & $\begin{array}{l}\text { Hindered the breast } \\
\text { cancer cell } \\
\text { progression by } \\
\text { inducing apoptosis } \\
\text { and cell cycle arrest } \\
\text { at } S \text { and } G_{0} / G_{1} \text { phase }\end{array}$ & HL-60 & $(0.91 \pm 0.05)$ & $\begin{array}{l}\text { Ursolic acid } \\
\qquad(40)\end{array}$ & $\begin{array}{c}\text { Doxorubicin } \\
(0.63)\end{array}$ & {$[88,89]$} \\
\hline 43 & $\begin{array}{c}\text { Induced apoptosis } \\
\text { and cell cycle arrest } \\
\text { in HepG2, HeLa, and } \\
\text { Jurkat cell lines }\end{array}$ & \multirow{3}{*}{$\begin{array}{l}\text { Jurkat } \\
\text { HeLa } \\
\text { HepG2 }\end{array}$} & $\begin{array}{c}(1.4 \pm 0.2) \\
(2.0 \pm 0.3) \\
(0.8 \pm 0.05)\end{array}$ & \multirow{3}{*}{$\begin{array}{l}\text { Betulinic acid } \\
(26.9 \pm 2.2) \\
(26.0 \pm 2.1) \\
(36.4 \pm 1.5)\end{array}$} & \multirow{3}{*}{ 一 } & \multirow{3}{*}{ [90] } \\
\hline 44 & n.r & & $\begin{array}{l}(2.3 \pm 0.3) \\
(3.0 \pm 0.2) \\
(1.7 \pm 0.2)\end{array}$ & & & \\
\hline 45 & n.r & & $\begin{array}{l}(11.1 \pm 1.3) \\
(3.0 \pm 0.2) \\
(2.0 \pm 0.4)\end{array}$ & & & \\
\hline 46 & $\begin{array}{c}\text { Antiproliferative, } \\
\text { Apoptosis induction } \\
\text { abilities correlated } \\
\text { with upregulation of } \\
\text { NOXA and } \\
\text { downregulation of } \\
\text { Bcl-xL }\end{array}$ & AsPC-1 & $(0.9 \pm 0.01)$ & $(>100)$ & - & [91] \\
\hline
\end{tabular}

Santos et al. [90] semi-synthesized novel BA derivatives (43, 44, and 45) (Figure 4, Table 2) with 18-45 times improved cytotoxic activity against HepG2 cell lines and induced apoptosis and cell cycle arrest in HepG2, HeLa, and Jurkat cell lines. The mechanism of apoptosis induction was mediated by the activation of the post mitochondrial caspases- 9 and -3 cascade and possibly by mitochondrial amplification loop involving caspase- 8 . Among these compounds, 43 is the most active compound with an $\mathrm{IC}_{50}$ value 45 times lower than BA on HepG2 cells and 61 times lower than those found for the non-tumoral Chang liver cells [90]. Leal et al. [91] synthesized a series of novel oleanane derivatives bearing imidazole carbamates, $\mathrm{N}$-alkylimidazoles or $\mathrm{N}$-acylimidazoles and evaluated their antiproliferative activity against AsPC-1 pancreatic cancer cell lines. The results revealed that the N-alkylimidazole 46 (Figure 4, Table 2) was the most active compound with apoptosis induction abilities correlated with upregulation of NOXA and downregulation of Bcl-xL. The antiproliferative activity of compound $\mathbf{4 6}$ was further tested in more solid tumor cell lines with $\mathrm{IC}_{50}$ values lower than $1 \mu \mathrm{M}$. 


\section{Indole}

Indole ring is one of the nitrogen heterocyclic compounds widely found in nature and commonly found in plant hormones, including tryptophan and auxins, serotonin or 5-hydroxytryptamine, and melatonin, which plays a significant role in the animal physiological and biochemical process [92]. The hybridization of indole with PTs is an effective strategy to search and develop novel anticancer candidates. The resulting single molecule containing one or more pharmacophores with different mechanisms of action may lead to the enhancement of the desired properties of the combined components and potentially reduce the drug resistance.

Anticancer Effects of Triterpenoid-based Indole Molecules

Khusnutdinova et al. prepared novel 2,3-Indolotriterpenic alcohols by successive modification of 3-oxo triterpenic acids (Fisher reaction, reduction of $\mathrm{C} 17-\mathrm{COOH}$, cyanoethylation) (Scheme 2) and evaluated them for in vitro antitumor activity. Compounds 2,3-indolouvaol (51) and 2,3-indolo-28-cyanoethoxybetulin (53) showed potential in vitro antitumor activity against NCI-H522 and COLO 205 cells, inducing the death of $12.65 \%$ and $42.78 \%$ of these cells, respectively [93].


Scheme 2. Conditions: (a), LiAlH4, THF, 2 h; (b), CH2=CHCN, 30\% KOH, TEBAC, 1,4-dioxane, 5 h.

Khusnutdinova et al. [94] attempted the modification of the carboxyl group of [3,2b]indolotriterpenic acids (N-propargylation, $\mathrm{Cu}(\mathrm{I})$ catalyzed Mannich reaction) with $\mathrm{N}$ methylpiperazine and morpholine moiety. Among the modified compounds, oleananetype conjugate with N-methylpiperazine 56 (Figure 5) displayed the highest anticancer potency against leukemia cell line SR $(-2.2 \%)$ and nonsmall cell lung cancer cell line NCI-H460 (-25.3\%). Tang et al. [95] designed and synthesized a series of novel oleanolic acid-based C(6)-indole substituted celastrol analogues. Among all these semisynthetic analogues, compounds 57 and 58 (Figure 5) displayed excellent in vitro antiproliferative activities against Bel7402 cancer cells with $\mathrm{IC}_{50}$ values of $0.02 \mu \mathrm{M}$ and $0.01 \mu \mathrm{M}$, respectively [95]. Fan et al. [96] synthesized a series of ursolic acid-based indole derivatives with compound $59(\mathrm{p}<0.05)$ (Figure 5), showing promising therapeutic effects against the growth of U251 and C6 glioma cells at a concentration of $10 \mu \mathrm{M}$. This compound inhibited glioma cell development, induced apoptosis, and cell cycle arrest in the G0/G1 phase with decreasing population in the G2/M and S phases via the down-regulation metabolic pathways. This compound is a potential anticancer agent for the treatment of glioma [96]. 

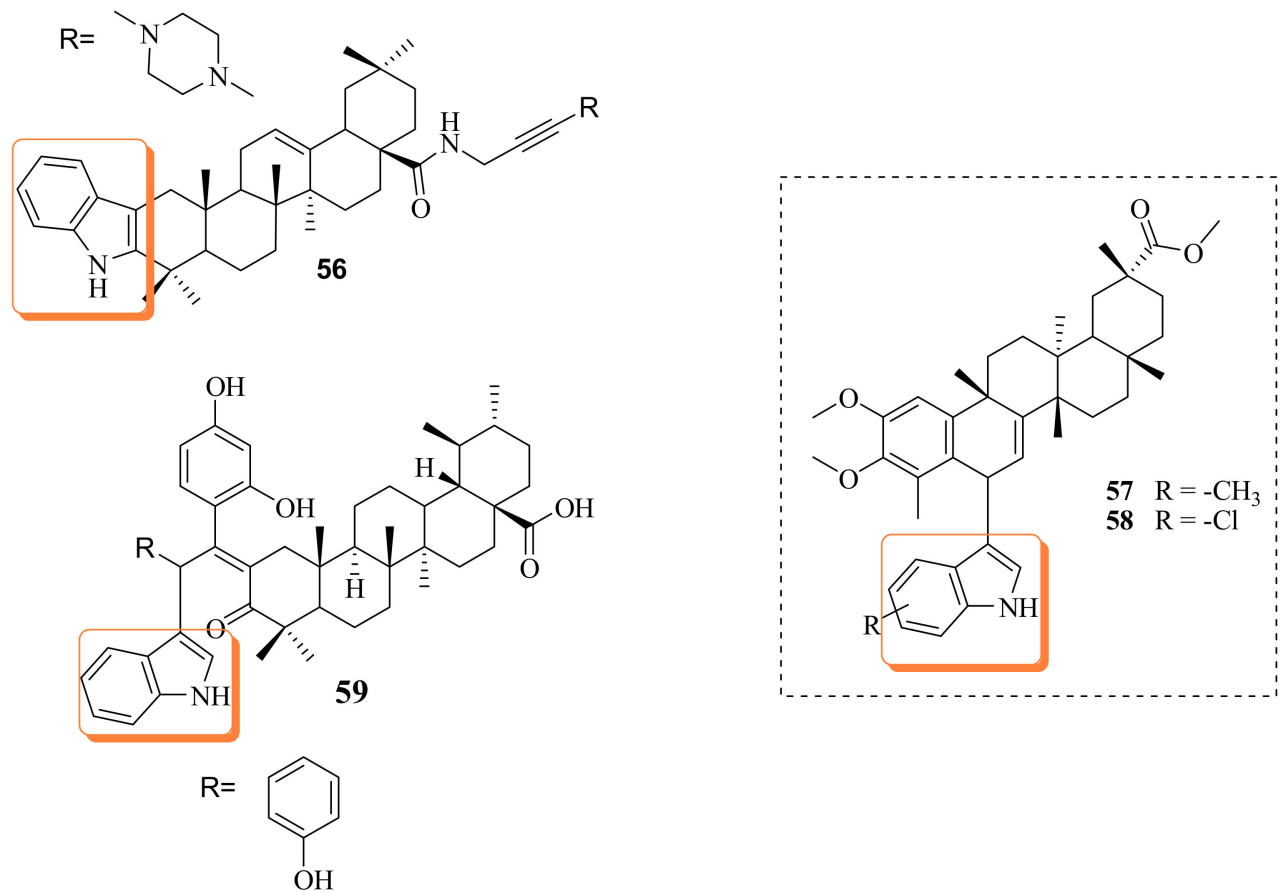

Figure 5. Oleanolic and ursolic acid-based indole hybrids.

\section{Piperazine}

The piperazine is a nitrogen-containing heterocyclic ring known for its medicinal importance. It is considered the most attractive scaffold for the development of novel anticancer agents [97]. In 2016, Rathi and co-workers [98] published a review of the anticancer potential of piperazine derivatives. Molecular hybridization has been identified as one of the successful strategies for developing novel chemotherapeutic candidates involving the combination of two or more different bioactive fragments. The combination of PTs and piperazine into a single-molecule (hybrid) has been reported with potential anticancer activity. Compounds methyl 3-O-[4-(1-piperazinyl)-4-oxo-butyryl]olean-12-ene-28-oate (60) and compound 2-O-[4-(1-piperazinyl)-4-oxo-butyryl]-3,23-dihydroxyurs-12-ene-28oate (61) were synthesized by Zhao et al. [99]. These compounds were evaluated for their biological activity using the Cell Counting Kit-8 method, and Western blotting analysis on A549 cells, MCF-7cells, and Hela cells. Both compounds 60 and $\mathbf{6 1}$ exhibited excellent anticancer activity than the reference drug, Gefitini [99]. Giniyatullina et al. [100] synthesized A-azepanobetulinic acid $N$-methylpiperazinylamide through a series of transformations (oximation, Beckmann, reduction) of $N$-methylpiperazinylamide. They evaluated their in vitro cytotoxicity against some cell lines, namely LNCAP, PC3 22RW1, Huh7, and VA13. Compounds 62 and 63 (Figure 6, Table 3) displayed the most potent cytotoxicity against the five cancer cell lines with an $\mathrm{IC}_{50}$ ranging from $0.37 \mu \mathrm{M}$ to $3.58 \mu \mathrm{M}$ [100]. Compound 64 (Figure 6, Table 3) effectively induced cell apoptosis in HepG2 cells [101]. 



Figure 6. Ursolic acid and betulinic acid-based indole hybrids

The ursolic acid derivative 65 with an acyl piperazine moiety at C-28 was synthesized by treating ursolic acid with ethylene dibromide $\left(\mathrm{C}_{2} \mathrm{H}_{4} \mathrm{Br}_{2}\right)$ in Dimethylformamide (DMF) for $24 \mathrm{~h}$. The obtained compound was introduced with piperazine in DMF in the presence of Potassium carbonate $\left(\mathrm{K}_{2} \mathrm{CO}_{3}\right)$ at $80{ }^{\circ} \mathrm{C}$, and then reacted with an aromatic to obtain the targeted compound. The newly synthesized compound was evaluated for anticancer activity against human gastric cancer (MGC-803) and breast cancer (Bcap-37) cell lines using standard MTT assay in vitro. The compound showed a cell apoptosis-inducing effect higher than the positive control, HCPT, and UA [102]. Wang et al. [103] designed and synthesized 19 new nitrogen heterocycle-containing ursolic acid derivatives and evaluated their potential antiproliferative activity against the cervical (Hela) and gastric (MKN45) cell lines. The potent anticancer compound was found to be compound 66 (Figure 7, Table 3) with $\mathrm{IC}_{50}$ values of $2.6 \mu \mathrm{M}$ and $2.1 \mu \mathrm{M}$. The study of the mechanism and the in vivo antitumor study of this compound demonstrated reduced apoptosis regulator (Bcl2/Bax) ratio, disrupted mitochondrial potential and induced apoptosis, and suppressed the growth of Hela xenografts in nude mice [103]. Li et al. [88] indicated that apoptosis in breast cancer cells was induced by ursolic acid piperazine hybrid derivative (compound $\mathbf{6 7}$ (Figure 6)), along with cell cycle arrest induction at S and G0/G1 phase. Thus, compound 67 is a promising therapeutic agent for the treatment of breast cancer. With earlier literature report by Chen et al. [89] suggesting the therapeutic potential of a similar compound against leukemia as summarized in Table 3 [89]. Kahnt et al. [104] prepared 11 conjugates containing piperizine hybrid heterocycles. Amongst all the ursolic acid derivatives, compound 68 was most potent with $\mathrm{EC}_{50}$ values of $1.5 \mu \mathrm{M}$ for $\mathrm{A} 375$ melanoma and $1.7 \mu \mathrm{M}$ for A2780 ovarian carcinoma) [104]. 
Table 3. Mechanism and cytotoxicity of PT-based piperazine scaffolds on different cancer cells.

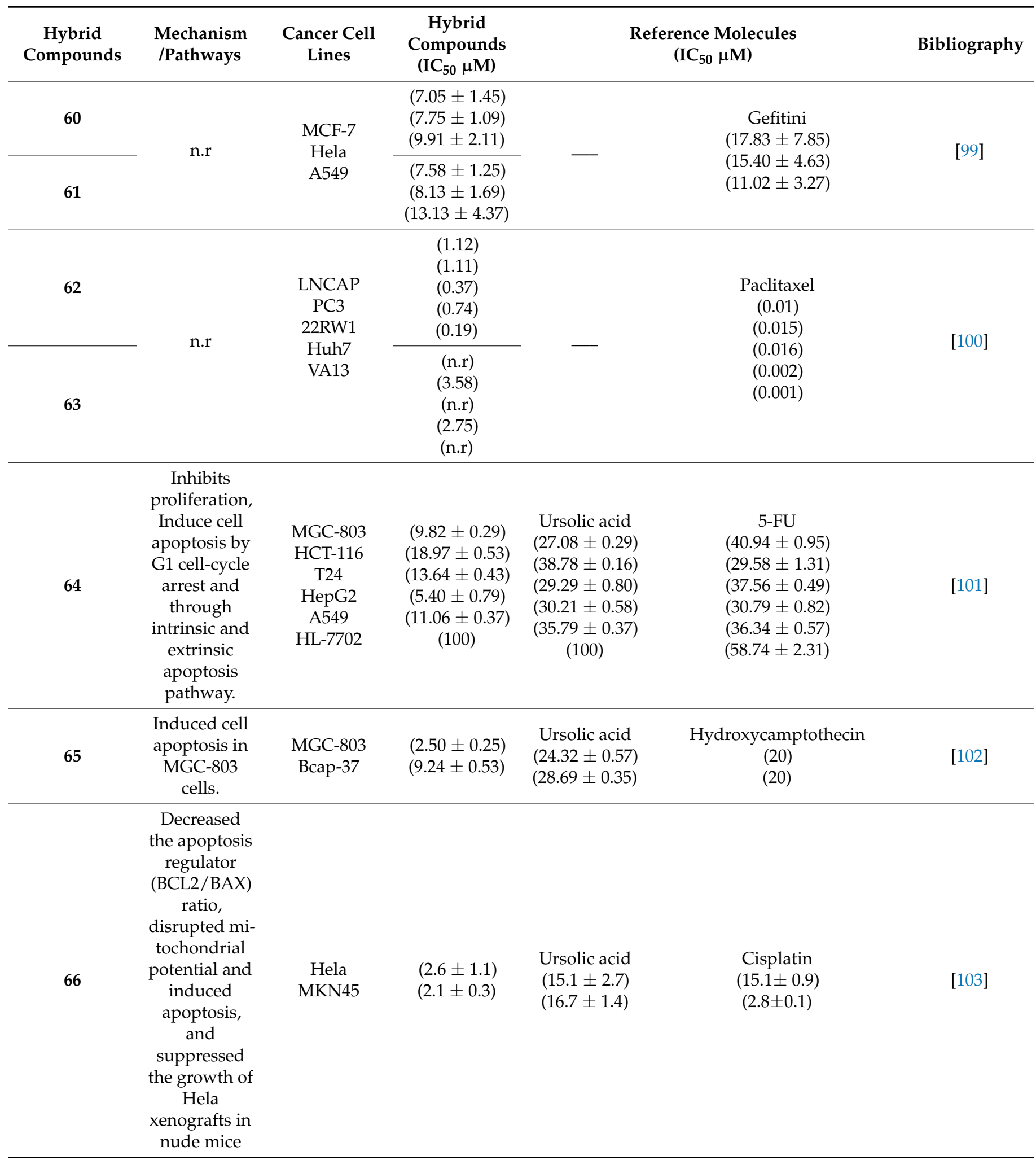


Table 3. Cont.

\begin{tabular}{|c|c|c|c|c|c|c|}
\hline $\begin{array}{c}\text { Hybrid } \\
\text { Compounds }\end{array}$ & $\begin{array}{l}\text { Mechanism } \\
\text { /Pathways }\end{array}$ & $\begin{array}{l}\text { Cancer Cell } \\
\text { Lines }\end{array}$ & $\begin{array}{c}\text { Hybrid } \\
\text { Compounds } \\
\left(\mathrm{IC}_{50} \mu \mathrm{M}\right)\end{array}$ & \multicolumn{2}{|c|}{$\begin{array}{l}\text { Reference Molecules } \\
\qquad\left(\mathrm{IC}_{50} \mu \mathrm{M}\right)\end{array}$} & Bibliography \\
\hline 68 & $\begin{array}{l}\text { Cytotoxicity } \\
\text { through } \\
\text { fluorescence } \\
\text { microscopy, } \\
\text { annexin V } \\
\text { assays and } \\
\text { cell } \\
\text { cycle } \\
\text { analysis. }\end{array}$ & $\begin{array}{c}\text { A375 } \\
\text { A2780 } \\
\text { HT29 } \\
\text { MCF-7 } \\
\text { FaDu } \\
\text { NIH 3T3 }\end{array}$ & $\begin{array}{l}(1.5 \pm 0.4) \\
(1.9 \pm 0.3) \\
(5.7 \pm 0.5) \\
(4.4 \pm 0.7) \\
(3.7 \pm 0.6) \\
(4.6 \pm 1.0)\end{array}$ & $\begin{array}{c}\text { Ursolic acid } \\
\text { (n.r) } \\
(11.7 \pm 0.6) \\
(10.6 \pm 0.7) \\
(12.7 \pm 0.1) \\
\text { (n.r) } \\
(13.1 \pm 1.1)\end{array}$ & $\begin{array}{c}\text { Doxorubici } \\
\text { (n.r) } \\
(0.01 \pm 0.01) \\
(0.9 \pm 0.2) \\
(1.1 \pm 0.3) \\
\text { (n.r) } \\
(0.06 \pm 0.03)\end{array}$ & [104] \\
\hline
\end{tabular}

n.r = reported.

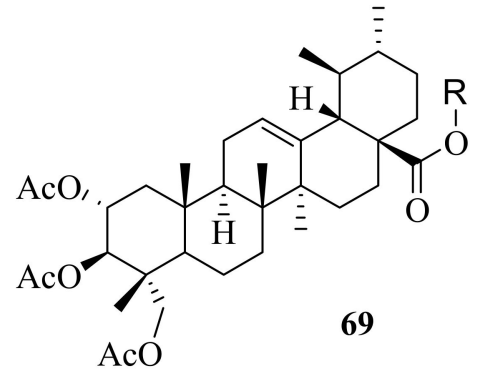<smiles>[R]NC(=O)C1C[C@H](C(=C)C)C2CC[C@]3(C)C(CCC4[C@@]5(C)CC[C@H](OC(C)=O)C(C)(C)[C@@H]5CC[C@]43C)C12</smiles>

69,70

<smiles>C#CC(=O)OCC1C[C@H](C(=C)C)C2C1CC[C@@]1(C)C2CC[C@]2(C)C1CCC1C(=O)C3N=CC=CC3C(=O)C(Cl)=C3O[C@@H](CC[C@@]12C)C3(C)C</smiles><smiles>O=C1C=C(Cl)C2CCCCC1C2=O</smiles>

Figure 7. Ursolic acid and betulinic triterpenic analogues with amminoquinoline heterocyclic hybrid scaffold.

\section{Aminoquinolines}

The principle of molecular hybridization is efficient as it is centered on the combination of two different distinct pharmacophores by linking covalently two or more structural entities with distinct biological functions. The positive synergistic effects of these compounds can also occur along with expected pharmacokinetic and pharmacodynamic profiles. In addition, by enhancing bioavailability and distribution through cell membranes of cell organelles, this process can solve a variety of common problems associated with drug molecules and shielding active compounds from enzyme degradation [105]. 
Quinones are a large and substantial family of cyclic compounds combined with a large variety of medicinal agents for therapeutic applications [106]. Figure 7 represents ursolic acid and betulinic triterpenic hybrids (69-71) with aminoquinoline heterocyclic scaffold. Sommerwerk et al. [107] synthesized a series of pentacyclic triterpenic derivatives and tested their activity against a number of human cancer cells using SRB assay to access their cytotoxicity. A triacetylated 4-isoquinolinyl derived compound of asiatic acid (69) was the most promising compound with $\mathrm{IC}_{50}$ values of $0.19 \mu \mathrm{M}$ for melanoma (518A2), $0.22 \mu \mathrm{M}$ for colorectal adenocarcinoma (HT29), $0.54 \mu \mathrm{M}$ for breast (MCF7), $0.29 \mu \mathrm{M}$ for lung adenocarcinoma (A549), $0.08 \mu \mathrm{M}$ for ovarian (A2780) and $3.23 \mu \mathrm{M}$ nonmalignant mouse fibroblast (NiH3T3). This compound was further examined by apoptosis through propidium iodide/acridine orange staining, fluorescence spectroscopy, and cell cycle investigation [107]. Hoenke et al. [108] synthesized a sequence of betulinic acid amide derivatives in an attempt to investigate their activity against some cancer cell lines compared to NiH3T3. Compound 70 was the most cytotoxic and therefore showed lower $\mathrm{EC}_{50}$ values of $1.48 \pm 0.1 \mu \mathrm{M}$ for melanoma (A375), $4.65 \pm 0.5 \mu \mathrm{M}$ (MCF7), $2.16 \pm 0.2 \mu \mathrm{M}$ (A2780), $2.26 \pm 0.2 \mu \mathrm{M}$ for hypopharyngeal carcinoma $(\mathrm{FaDu})$ and $>30 \mu \mathrm{M}$ (HT29) compared to $>91.2 \mu \mathrm{M}$ (NiH3T3). On the other hand, doxorubicin was used as a reference drug with $\mathrm{EC}_{50}$ values of $>30 \mu \mathrm{M}$ (HT29), $1.1 \pm 0.3 \mu \mathrm{M}$ (MCF7), $0.01 \pm 0.01 \mu \mathrm{M}$ (A2780), not detected for A375 and FaDu compared to $1.3 \pm 0.6 \mu \mathrm{M}$ (NiH3T3). Therefore compound 62 can be further investigated as a antitumor agent [108]. Kadela-Tomanek et al. [109] synthesized Betulin-1,4-quinone hybrids using a linker method of combining two active structures in an attempt to produce a more biologically active derivatives with anticancer activity and better bioavailability. The synthesized derivatives were tested in vitro against a number of human cancer cells such as breast (MCF-7, T47D, and MDA-MB-231), melanoma (C-32), lung (A549), colon (Colo-8), and gliblastoma (SNB-19). They found out that their derivatives were cytotoxic towards the cancer cells with NAD[P[H-quinone oxidoreductase (NQO1) protein level namely MC-7, C-32 and A549. Compound 71 was the most promising hybrid with $\mathrm{IC}_{50}$ values of $1.27 \pm 0.06 \mu \mathrm{M}$ (C-32), $2.43 \pm 0.68 \mu \mathrm{M}$ (MDA-MB-231), $6.67 \pm 1.30 \mu \mathrm{M}$ (Colo-8), $14.9 \pm 2.30 \mu \mathrm{M}$ (MCF-7). However, its cytotoxicity against SNB-19 and T47D was not impressive with $\mathrm{IC}_{50}$ values of $41.99 \pm 0.11 \mu \mathrm{M}$ and $99.39 \pm 6.98 \mu \mathrm{M}$, respectively. Compound $\mathbf{7 1}$ reduced the proliferative activity of all tested cells during enzymatic mechanism of action. This compound was tested for its transcriptional activity of gene encoding of cell-cycle (p21 and p53), proliferation maker (H3-histone) and apoptosis. Furthermore, this compound interacted with hydrophobic matrix of the active site of the enzyme near FAD, Trp105, Phe178, and Tyr128 cofactor, which was observed by an increase in gene expression (TP53) [109].

\section{Perspectives and Concluding Remarks}

The growing incidences of cancer are one of the major issues in the developing world. Novel therapeutic agents that would be useful for the treatment of cancers that have acquired resistance to the existing drugs are desperately needed. PTs have the advantage of creating various derivatives with potential pharmacological properties. This review summarized the synthesized PTs derivatives with fused nitrogen-containing heterocyclic scaffolds, which have displayed significant anticancer activity. We noted that recent studies had been done on triterpenoid with nitrogen-containing heterocyclic scaffolds to understand the mechanism of action of these hybrids. The introduction of various nitrogen-containing heterocyclic moieties in PTs brings new mechanism of actions that lead to high anticancer activity. The hybrid compounds exhibited high anticancer activity such as 18, (36a-36d), 43, 44, 45, 46, and 68. Some hybrid compounds have been reported to be the modulators for multiple targets at different stages of cancer progression, such as proliferation, angiogenesis, metastasis, and apoptosis. Almost all the reported hybrid compounds displayed enhanced anticancer activity compared to the parent PTs. The above-mentioned significant points identify the enormous potential of these triterpenoid- 
based nitrogen-containing heterocyclic moieties in pharmaceutical applications suggesting a massive scope for these promising compounds because of their diverse molecular targets.

Funding: This research was funded by the South African Medical Research Council (self-initiated research), National Research Foundation South Africa, Sasol Inzalo Foundation, and Govan Mbeki Research and Development Centre (GMRDC), University of Fort Hare.

Acknowledgments: This study was financed by the South African Medical Research Council (SelfInitiated Research), National Research Foundation South Africa, Sasol Inzalo Foundation, and Govan Mbeki Research and Development Centre (GMRDC), University of Fort Hare.

Conflicts of Interest: The authors declare no conflict of interest.

\section{References}

1. Alves-Silva, J.M.; Romane, A.; Efferth, T.; Salgueiro, L. North African medicinal plants traditionally used in cancer therapy. Front. Pharmacol. 2017, 8, 383. [CrossRef] [PubMed]

2. Tariq, A.; Sadia, S.; Pan, K.; Ullah, I.; Mussarat, S.; Sun, F.; Abiodun, O.O.; Batbaatar, A.; Li, Z.; Song, D.; et al. A systematic review on ethnomedicines of anti-cancer plants. Phyther. Res. 2017, 31, 202-264. [CrossRef] [PubMed]

3. Singh, S.; Sharma, B.; Kanwar, S.S.; Kumar, A. Lead phytochemicals for anticancer drug development. Front. Plant Sci. 2016, 7, 1667. [CrossRef] [PubMed]

4. Sharma, H.; Kumar, P.; Deshmukh, R.R.; Bishayee, A.; Kumar, S. Pentacyclic triterpenes: New tools to fight metabolic syndrome. Phytomedicine 2018, 50, 166-177. [CrossRef] [PubMed]

5. Borková, L.; Frydrych, I.; Jakubcová, N.; Adámek, R.; Lišková, B.; Gurská, S.; Medvedíková, M.; Hajdúch, M.; Urban, M. Synthesis and biological evaluation of triterpenoid thiazoles derived from betulonic acid, dihydrobetulonic acid, and ursonic acid. Eur. J. Med. Chem. 2020, 185, 111806. [CrossRef] [PubMed]

6. Kamble, S.M.; Goyal, S.N.; Patil, C.R. Multifunctional pentacyclic triterpenoids as adjuvants in cancer chemotherapy: A review. RSC Adv. 2014, 4, 33370-33382. [CrossRef]

7. Herrera-España, A.D.; Us-Martín, J.; Hernández-Ortega, S.; Mirón-López, G.; Quijano, L.; Villanueva-Toledo, J.R.; Mena-Rejón, G.J. Synthesis, structure analysis and activity against breast and cervix cancer cells of a triterpenoid thiazole derived from ochraceolide A. J. Mol. Struct. 2020, 1204, 127555. [CrossRef]

8. Han, B.; Peng, Z. Anti-HIV triterpenoid components. J. Chem. Pharm. Res. 2014, 6, 438-443.

9. Medina-O'Donnell, M.; Rivas, F.; Reyes-Zurita, F.J.; Cano-Muñoz, M.; Martinez, A.; Lupiañez, J.A.; Parra, A. Oleanolic Acid Derivatives as Potential Inhibitors of HIV-1 Protease. J. Nat. Prod. 2019, 82, 2886-2896. [CrossRef]

10. Kaur, R.; Sharma, P.; Gupta, G.K.; Ntie-Kang, F.; Kumar, D. Structure-activity-relationship and mechanistic insights for anti-HIV natural products. Molecules 2020, 25, 2070. [CrossRef]

11. Bednarczyk-Cwynar, B.; Wachowiak, N.; Szulc, M.; Kamińska, E.; Bogacz, A.; Bartkowiak-Wieczorek, J.; Zaprutko, L.; Mikolajczak, P.L. Strong and long-lasting antinociceptive and anti-inflammatory conjugate of naturally occurring oleanolic acid and aspirin. Front. Pharmacol. 2016, 7, 202. [CrossRef] [PubMed]

12. Fukumitsu, S.; Villareal, M.O.; Fujitsuka, T.; Aida, K.; Isoda, H. Anti-inflammatory and anti-arthritic effects of pentacyclic triterpenoids maslinic acid through NF-kB inactivation. Mol. Nutr. Food Res. 2016, 60, 399-409. [CrossRef]

13. Prachayasittikul, S.; Saraban, P.; Cherdtrakulkiat, R.; Ruchirawat, S.; Prachayasittikul, V. New bioactive triterpenoids and antimalarial activity of Diospyros rubra Lec. EXCLI J. 2010, 9, 1. [PubMed]

14. Wang, G.W.; Deng, L.Q.; Luo, Y.P.; Liao, Z.H.; Chen, M. Hepatoprotective triterpenoids and lignans from the stems of Schisandra pubescens. Nat. Prod. Res. 2017, 31, 1855-1860. [CrossRef] [PubMed]

15. Xu, G.B.; Xiao, Y.H.; Zhang, Q.Y.; Zhou, M.; Liao, S.G. Hepatoprotective natural triterpenoids. Eur. J. Med. Chem. 2018, 145, 691-716. [CrossRef]

16. Chung, P.Y. Novel targets of pentacyclic triterpenoids in Staphylococcus aureus: A systematic review. Phytomedicine 2020, 73, 152933. [CrossRef]

17. Spivak, A.Y.; Khalitova, R.R.; Nedopekina, D.A.; Gubaidullin, R.R. Antimicrobial properties of amine-and guanidine-functionalized derivatives of betulinic, ursolic and oleanolic acids: Synthesis and structure/activity evaluation. Steroids 2020, 154, 108530. [CrossRef]

18. Beinke, C.; Scherthan, H.; Port, M.; Popp, T.; Hermann, C.; Eder, S. Triterpenoid CDDO-Me induces ROS generation and up-regulates cellular levels of antioxidative enzymes without induction of DSBs in human peripheral blood mononuclear cells. Radiat. Environ. Biophys. 2020, 59, 461-472. [CrossRef]

19. Choi, C.W.; Jung, H.A.; Kang, S.S.; Choi, J.S. Antioxidant constituents and a new triterpenoid glycoside from Flos Lonicerae. Arch. Pharm. Res. 2007, 30, 1. [CrossRef]

20. Banerjee, S.; Bose, S.; Mandal, S.C.; Dawn, S.; Sahoo, U.; Ramadan, M.A.; Mandal, S.K. Pharmacological Property of Pentacyclic Triterpenoids. Egypt. J. Chem. 2019, 62, 13-35. [CrossRef]

21. Csuk, R. Betulinic acid and its derivatives: A patent review (2008-2013). Expert Opin. Ther. Pat. 2014, 24, 913-923. [CrossRef] [PubMed] 
22. Cao, J.; Zhang, X.; Qu, F.; Guo, Z.; Zhao, Y. Dammarane triterpenoids for pharmaceutical use: A patent review (2005-2014). Expert Opin. Ther. Pat. 2015, 25, 805-817. [CrossRef] [PubMed]

23. Kashyap, D.; Sharma, A.; Tuli, H.S.; Punia, S.; Sharma, A.K. Ursolic acid and oleanolic acid: Pentacyclic terpenoids with promising anti-inflammatory activities. Recent Pat. Inflamm. Allergy Drug Discov. 2016, 10, 21-33. [CrossRef] [PubMed]

24. Sporn, M.B.; Liby, K.T.; Gribble, G.W.; Honda, T.; Kral, R.M.; Meyer, C.J. Dartmouth College and Reata Pharmaceuticals Inc. Synthetic Triterpenoids and Methods of Use in the Treatment of Disease. U.S. Patent 8,129,429, 6 March 2012.

25. Yan, X.J.; Gong, L.H.; Zheng, F.Y.; Cheng, K.J.; Chen, Z.S.; Shi, Z. Triterpenoids as reversal agents for anticancer drug resistance treatment. Drug Discov. Today 2014, 19, 482-488. [CrossRef] [PubMed]

26. Kvasnica, M.; Urban, M.; Dickinson, N.J.; Sarek, J. Pentacyclic triterpenoids with nitrogen-and sulfur-containing heterocycles: Synthesis and medicinal significance. Nat. Prod. Rep. 2015, 32, 1303-1330. [CrossRef]

27. Zhou, M.; Zhang, R.H.; Wang, M.; Xu, G.B.; Liao, S.G. Prodrugs of triterpenoids and their derivatives. Eur. J. Med. Chem. 2017, 131, 222-236. [CrossRef]

28. Kerru, N.; Bhaskaruni, S.V.; Gummidi, L.; Maddila, S.N.; Maddila, S.; Jonnalagadda, S.B. Recent advances in heterogeneous catalysts for the synthesis of imidazole derivatives. Synth. Commun. 2019, 49, 2437-2459. [CrossRef]

29. Kalaria, P.N.; Karad, S.C.; Raval, D.K. A review on diverse heterocyclic compounds as the privileged scaffolds in antimalarial drug discovery. Eur. J. Med. Chem. 2018, 158, 917-936. [CrossRef]

30. World Health Organisation. Internation Agency for Research on Cancer. 2018. Available online: https://www.who.int/cancer/ PRGlobocanFinal.pdf (accessed on 8 October 2020).

31. Khotimchenko, M. Pectin polymers for colon-targeted antitumor drug delivery. Int. J. Biol. Macromol. 2020, 158, 1110-1124. [CrossRef]

32. Rodrigues, F.C.; Kumar, N.A.; Thakur, G. Developments in the anticancer activity of structurally modified curcumin: An up-todate review. Eur. J. Med. Chem. 2019, 177, 76-104. [CrossRef]

33. Khwaza, V.; Oyedeji, O.O.; Aderibigbe, B.A. Ursolic acid-based derivatives as potential anti-cancer agents: An update. Int. J. Mol. Sci. 2020, 21, 5920. [CrossRef] [PubMed]

34. Selvam, C.; Prabu, S.L.; Jordan, B.C.; Purushothaman, Y.; Umamaheswari, A.; Zare, M.S.H.; Thilagavathi, R. Molecular mechanisms of curcumin and its analogs in colon cancer prevention and treatment. Life Sci. 2019, 239, 117032. [CrossRef] [PubMed]

35. Babalola, I.T.; Shode, F.O. Ubiquitous ursolic acid: A potential pentacyclic triterpene natural product. J. Pharmacogn. Phytochem. 2013, 2, 214-222.

36. Khwaza, V.; Oyedeji, O.O.; Aderibigbe, B.A. Antiviral activities of oleanolic acid and its analogues. Molecules 2018, 23, 2300. [CrossRef] [PubMed]

37. Dzubak, P.; Hajduch, M.; Vydra, D.; Hustova, A.; Kvasnica, M.; Biedermann, D.; Markova, L.; Urban, M.; Sarek, J. Pharmacological activities of natural triterpenoids and their therapeutic implications. Nat. Prod. Rep. 2006, 23, 394-411. [CrossRef]

38. Shanmugam, M.K.; Nguyen, A.H.; Kumar, A.P.; Tan, B.K.; Sethi, G. Targeted inhibition of tumor proliferation, survival, and metastasis by pentacyclic triterpenoids: Potential role in prevention and therapy of cancer. Cancer Lett. 2012, 320, 158-170. [CrossRef]

39. Smith, P.F.; Ogundele, A.; Forrest, A.; Wilton, J.; Salzwedel, K.; Doto, J.; Allaway, G.P.; Martin, D.E. Phase I and II study of the safety, virologic effect, and pharmacokinetics / pharmacodynamics of single-dose 3-o-( $3^{\prime}, 3^{\prime}$-dimethylsuccinyl) betulinic acid (bevirimat) against human immunodeficiency virus infection. Antimicrob. Agents Chemother. 2007, 51, 3574-3581. [CrossRef]

40. Dang, Z.; Ho, P.; Zhu, L.; Qian, K.; Lee, K.H.; Huang, L.; Chen, C.H. New betulinic acid derivatives for bevirimat-resistant human immunodeficiency virus type-1. J. Med. Chem. 2013, 56, 2029-2037. [CrossRef]

41. Xu, H.; Ji, L.; Yu, C.; Chen, Q.; Ge, Q.; Lu, Y. MiR-423-5p Regulates Cells Apoptosis and Extracellular Matrix Degradation via Nucleotide-Binding, Leucine-Rich Repeat Containing X1 (NLRX1) in Interleukin 1 beta (IL-1 $\beta$ )-Induced Human Nucleus Pulposus Cells. Med. Sci. Monit. 2020, 26, e922497. [CrossRef]

42. Manu, K.A.; Kuttan, G. Ursolic acid induces apoptosis by activating p53 and caspase-3 gene expressions and suppressing NF- $\mathrm{B}$ mediated activation of bcl-2 in B16F-10 melanoma cells. Int. Immunopharmacol. 2008, 8, 974-981. [CrossRef]

43. Pengyue, Z.; Tao, G.; Hongyun, H.; Liqiang, Y.; Yihao, D. Breviscapine confers a neuroprotective efficacy against transient focal cerebral ischemia by attenuating neuronal and astrocytic autophagy in the penumbra. Biomed. Pharmacother. 2017, 90, 69-76. [CrossRef] [PubMed]

44. Byun, H.S.; Zhou, W.; Park, I.; Kang, K.; Lee, S.R.; Piao, X.; Park, J.B.; Kwon, T.K.; Na, M.; Hur, G.M. C-27-carboxylated oleanane triterpenoids up-regulate TRAIL DISC assembly via p38 MAPK and CHOP-mediated DR5 expression in human glioblastoma cells. Biochem. Pharmacol. 2018, 158, 243-260. [CrossRef] [PubMed]

45. Wang, W.; Zhao, C.; Jou, D.; Lü, J.; Zhang, C.; Lin, L.; Lin, J. Ursolic acid inhibits the growth of colon cancer-initiating cells by targeting STAT3. Anticancer Res. 2013, 33, 4279-4284. [PubMed]

46. El Bourakadi, K.; Mekhzoum, M.E.M.; Saby, C.; Morjani, H.; Chakchak, H.; Merghoub, N.; Bouhfid, R. Synthesis, characterization and in vitro anticancer activity of thiabendazole-derived 1, 2, 3-triazole derivatives. New J. Chem. 2020, 44, 12099-12106. [CrossRef]

47. Pokhodylo, N.; Shyyka, O.; Matiychuk, V. Synthesis and anticancer activity evaluation of new 1, 2, 3-triazole-4-carboxamide derivatives. Med. Chem. Res. 2014, 23, 2426-2438. [CrossRef]

48. Louie, T.; Goodman, C.D.; Holloway, G.A.; McFadden, G.I.; Mollard, V.; Watson, K.G. Dimeric cyclohexane-1, 3-dione oximes inhibit wheat acetyl-CoA carboxylase and show anti-malarial activity. Bioorg. Med. Chem. Lett. 2010, 20, 4611-4613. [CrossRef]

49. Batra, N.; Rajendran, V.; Wadi, I.; Lathwal, A.; Dutta, R.K.; Ghosh, P.C.; Gupta, R.D.; Nath, M. Synthesis, characterization, and antiplasmodial efficacy of sulfonamide-appended [1,2,3]-triazoles. J. Heterocycl. Chem. 2020, 57, 1625-1636. [CrossRef] 
50. Tan, W.; Li, Q.; Wang, H.; Liu, Y.; Zhang, J.; Dong, F.; Guo, Z. Synthesis, characterization, and antibacterial property of novel starch derivatives with 1, 2, 3-triazole. Carbohydr. Polym. 2016, 142, 1-7. [CrossRef]

51. Nejadshafiee, V.; Naeimi, H.; Zahraei, Z. Efficient synthesis and antibacterial evaluation of some substituted $\beta$-hydroxy-1, 2, 3-triazoles. Chem. Data Collect. 2020, 28, 100443. [CrossRef]

52. Dai, Z.; Chen, Y.; Zhang, M.; Li, S.; Yang, T.; Shen, L.; Wang, J.; Qian, S.; Zhu, H.; Ye, Y. Synthesis and Antifungal Activity of 1,2,3-Triazole Phenylhydrazone Derivatives. Org. Biomol. Chem. 2015, 13, 10715-10722. [CrossRef]

53. Aher, N.G.; Pore, V.S.; Mishra, N.N.; Kumar, A.; Shukla, P.K.; Sharma, A.; Bhat, M.K. Synthesis and antifungal activity of 1,2,3-triazole containing fluconazole analogues. Bioorg. Med. Chem. Lett. 2009, 19, 759-763. [CrossRef] [PubMed]

54. Chandrika, K.M.; Sharma, S. Promising antifungal agents: A minireview. Bioorganic Med. Chem. 2020, 28, 115398. [CrossRef] [PubMed]

55. Cheng, C.Y.; Haque, A.; Hsieh, M.F.; Imran Hassan, S.; Faizi, M.; Haque, S.; Dege, N.; Khan, M.S. 1, 4-Disubstituted 1H-1,2,3Triazoles for renal diseases: Studies of viability, anti-inflammatory, and antioxidant activities. Int. J. Mol. Sci. 2020, $21,3823$. [CrossRef] [PubMed]

56. He, Y.W.; Dong, C.Z.; Zhao, J.Y.; Ma, L.L.; Li, Y.H.; Aisa, H.A. 1,2,3-Triazole-containing derivatives of rupestonic acid: Clickchemical synthesis and antiviral activities against influenza viruses. Eur. J. Med. Chem. 2014, 76, 245-255. [CrossRef] [PubMed]

57. Cao, X.; Wang, W.; Wang, S.; Bao, L. Asymmetric synthesis of novel triazole derivatives and their in vitro antiviral activity and mechanism of action. Eur. J. Med. Chem. 2017, 139, 718-725. [CrossRef] [PubMed]

58. Xu, Z.; Zhao, S.J.; Liu, Y. 1,2,3-Triazole-containing hybrids as potential anticancer agents: Current developments, action mechanisms and structure-activity relationships. Eur. J. Med. Chem. 2019, 183, 111700. [CrossRef]

59. Thi, T.A.D.; Tuyet, N.T.K.; The, C.P.; Nguyen, H.T.; Thi, C.B.; Phuong, H.T.; Van Boi, L.; Van Nguyen, T.; D’hooghe, M. Synthesis and cytotoxic evaluation of novel amide-triazole-linked triterpenoid-AZT conjugates. Tetrahedron Lett. 2015, 56, 218-224.

60. Thi, T.A.D.; Tuyet, N.T.K.; The, C.P.; Nguyen, H.T.; Thi, C.B.; Duy, T.D.; D'hooghe, M.; Van Nguyen, T. Synthesis and cytotoxic evaluation of novel ester-triazole-linked triterpenoid-AZT conjugates. Bioorg. Med. Chem. 2014, 24, 5190-5194.

61. Majeed, R.; Sangwan, P.L.; Chinthakindi, P.K.; Khan, I.; Dangroo, N.A.; Thota, N.; Hamid, A.; Sharma, P.R.; Saxena, A.K.; Koul, S. Synthesis of 3-O-propargylated betulinic acid and its 1,2,3-triazoles as potential apoptotic agents. Eur. J. Med. Chem. 2013, 63, 782-792. [CrossRef]

62. Khan, I.; Guru, S.K.; Rath, S.K.; Chinthakindi, P.K.; Singh, B.; Koul, S.; Bhushan, S.; Sangwan, P.L. A novel triazole derivative of betulinic acid induces extrinsic and intrinsic apoptosis in human leukemia HL-60 cells. Eur. J. Med. Chem. 2016, 108, 104-116. [CrossRef]

63. Suman, P.; Patel, A.; Solano, L.; Jampana, G.; Gardner, Z.S.; Holt, C.M.; Jonnalagadda, S.C. Synthesis and cytotoxicity of Baylis-Hillman template derived betulinic acid-triazole conjugates. Tetrahedron 2017, 73, 4214-4226. [CrossRef]

64. Shi, W.; Tang, N.; Yan, W.D. Synthesis and cytotoxicity of triterpenoids derived from betulin and betulinic acid via click chemistry. J. Asian Nat. Prod. Res. 2015, 17, 159-169. [CrossRef] [PubMed]

65. Sidova, V.; Zoufaly, P.; Pokorny, J.; Dzubak, P.; Hajduch, M.; Popa, I.; Urban, M. Cytotoxic conjugates of betulinic acid and substituted triazoles prepared by Huisgen Cycloaddition from 30-azidoderivatives. PLoS ONE 2017, 12, 0171621. [CrossRef] [PubMed]

66. Chakraborty, B.; Dutta, D.; Mukherjee, S.; Das, S.; Maiti, N.C.; Das, P.; Chowdhury, C. Synthesis and biological evaluation of a novel betulinic acid derivative as an inducer of apoptosis in human colon carcinoma cells (HT-29). Eur. J. Med. Chem. 2015, 102, 93-105. [CrossRef] [PubMed]

67. Bębenek, E.; Jastrzębska, M.; Kadela-Tomanek, M.; Chrobak, E.; Orzechowska, B.; Zwolińska, K.; Latocha, M.; Mertas, A.; Czuba, Z.; Boryczka, S. Novel triazole hybrids of betulin: Synthesis and biological activity profile. Molecules 2017, $22,1876$. [CrossRef] [PubMed]

68. Zhu, R.X.; Zhao, L.; Zhang, Y.K.; Luo, P.; Liu, S.H.; Wang, J.G. Sequential treatment with ursolic acid chlorophenyl triazole followed by 5-fluorouracil shows synergistic activity in small cell lung cancer cells. Bangladesh J. Pharmacol. 2015, 10, 197-204. [CrossRef]

69. Wei, G.; Luan, W.; Wang, S.; Cui, S.; Li, F.; Liu, Y.; Liu, Y.; Cheng, M. A library of 1,2,3-triazole-substituted oleanolic acid derivatives as anticancer agents: Design, synthesis, and biological evaluation. Org. Biomol. Chem. 2015, 13, 1507-1514. [CrossRef]

70. Li, F.; Liu, Y.; Wang, S.; Wei, G.; Cheng, M. Synthesis and tumor cytotoxicity of novel 1, 2, 3-triazole-substituted 3-oxo-oleanolic acid derivatives. Chem. Res. Chin. Univ. 2016, 32, 938-942. [CrossRef]

71. Leal, A.S.; Wang, R.; Salvador, J.A.; Jing, Y. Synthesis of novel ursolic acid heterocyclic derivatives with improved abilities of antiproliferation and induction of p53, p21waf1 and NOXA in pancreatic cancer cells. Bioorg. Med. Chem. 2012, 20, 5774-5786. [CrossRef]

72. Pertino, M.W.; Lopez, C.; Theoduloz, C.; Schmeda-Hirschmann, G. 1,2,3-Triazole-substituted oleanolic acid derivatives: Synthesis and antiproliferative activity. Molecules 2013, 18, 7661. [CrossRef]

73. Lakshmi, J.K.; Pattnaik, B.; Kavitha, R.; Mallavadhani, U.V.; Jagadeesh, B. Conformation of flexibly linked triterpene dimers by using RDC-enhanced NMR spectroscopy. J. Mol. Struct 2018, 1162, 26-30. [CrossRef]

74. Pattnaik, B.; Lakshmi, J.K.; Kavitha, R.; Jagadeesh, B.; Bhattacharjee, D.; Jain, N.; Mallavadhani, U.V. Synthesis, structural studies, and cytotoxic evaluation of novel ursolic acid hybrids with capabilities to arrest breast cancer cells in mitosis. J. Asian Nat. Prod. Res. 2017, 19, 260-271. [CrossRef] [PubMed]

75. Popov, S.A.; Semenova, M.D.; Baev, D.S.; Frolova, T.S.; Shestopalov, M.A.; Wang, C.; Qi, Z.; Shults, E.E.; Turks, M. Synthesis and cytotoxicity of hybrids of 1,3, 4-or 1, 2, 5-oxadiazoles tethered from ursane and lupane core with 1, 2, 3-triazole. Steroids 2020, 162, 108698. [CrossRef] [PubMed] 
76. Rashid, S.; Dar, B.A.; Majeed, R.; Hamid, A.; Bhat, B.A. Synthesis and biological evaluation of ursolic acid-triazolyl derivatives as potential anti-cancer agents. Eur. J. Med. Chem. 2013, 66, 238-245. [CrossRef] [PubMed]

77. Fustero, S.; Sanchez-Rosello, M.; Barrio, P.; Simon-Fuentes, A. From 2000 to mid-2010: A fruitful decade for the synthesis of pyrazoles. Chem. Rev. 2011, 111, 6984-7034. [CrossRef]

78. Karrouchi, K.; Radi, S.; Ramli, Y.; Taoufik, J.; Mabkhot, Y.N.; Al-Aizari, F.A. Synthesis and pharmacological activities of pyrazole derivatives: A review. Molecules 2018, 23, 134. [CrossRef]

79. Ansari, A.; Ali, A.; Asif, M. Biologically active pyrazole derivatives. New J. Chem. 2017, 41, 16-41. [CrossRef]

80. Balbi, A.; Anzaldi, M.; Macciò, C.; Aiello, C.; Mazzei, M.; Gangemi, R.; Castagnola, P.; Miele, M.; Rosano, C.; Viale, M. Synthesis and biological evaluation of novel pyrazole derivatives with anticancer activity. Eur. J. Med. Chem. 2011, 46, 5293-5309. [CrossRef]

81. Puneeth, H.R.; Ananda, H.; Kumar, K.S.S.; Rangappa, K.S.; Sharada, A.C. Synthesis and antiproliferative studies of curcumin pyrazole derivatives. Med. Chem. Res. 2016, 25, 1842-1851. [CrossRef]

82. Ravula, P.; Vamaraju, H.B.; Paturi, M.; JN, N.S.C.; Kolli, S. Design, synthesis, in silico toxicity prediction, molecular docking, and evaluation of novel pyrazole derivatives as potential antiproliferative agents. EXCLI J. 2016, 15, 187.

83. Nitulescu, G.M.; Draghici, C.; Missir, A.V. Synthesis of new pyrazole derivatives and their anticancer evaluation. Eur. J. Med. Chem 2010, 45, 4914-4919. [CrossRef] [PubMed]

84. Insuasty, B.; Tigreros, A.; Orozco, F.; Quiroga, J.; Abonía, R.; Nogueras, M.; Sanchez, A.; Cobo, J. Synthesis of novel pyrazolic analogues of chalcones and their 3-aryl-4-(3-aryl-4, 5-dihydro-1H-pyrazol-5-yl)-1-phenyl-1H-pyrazole derivatives as potential antitumor agents. Bioorg. Med. Chem. 2010, 18, 4965-4974. [CrossRef] [PubMed]

85. Labbozzetta, M.; Baruchello, R.; Marchetti, P.; Gueli, M.C.; Poma, P.; Notarbartolo, M.; Simoni, D.; D'Alessandro, N. Lack of nucleophilic addition in the isoxazole and pyrazole diketone modified analogs of curcumin; implications for their antitumor and chemosensitizing activities hem. Biol. Interact. 2009, 181, 29-36. [CrossRef] [PubMed]

86. Bennani, F.E.; Doudach, L.; Cherrah, Y.; Ramli, Y.; Karrouchi, K.; Faouzi, M.E.A. Overview of recent developments of pyrazole derivatives as an anticancer agent in different cell line. Bioorg. Chem. 2020, 97, 103470. [CrossRef] [PubMed]

87. Sun, L.; Li, B.; Su, X.; Chen, G.; Li, Y.; Yu, L.; Li, L.; Wei, W. An ursolic acid derived small molecule triggers cancer cell death through hyperstimulation of macropinocytosis. J. Med. Chem. 2017, 60, 6638-6648. [CrossRef] [PubMed]

88. Li, W.; Zhang, H.; Nie, M.; Wang, W.; Liu, Z.; Chen, C.; Chen, H.; Liu, R.; Baloch, Z.; Ma, K. A novel synthetic ursolic acid derivative inhibits growth and induces apoptosis in breast cancer cell lines. Oncol. Lett. 2018, 15, 2323-2329. [CrossRef]

89. Chen, Y.; Li, C.; Zheng, Y.; Gao, Y.; Hu, J.; Chen, H. Discovery of FZU-03,010 as a self-assembling anticancer amphiphile for acute myeloid leukemia. Bioorg. Med. Chem. Lett. 2017, 27, 1007-1011. [CrossRef]

90. Santos, R.C.; Salvador, J.A.; Cortés, R.; Pachón, G.; Marín, S.; Cascante, M. New betulinic acid derivatives induce potent and selective antiproliferative activity through cell cycle arrest at the $\mathrm{S}$ phase and caspase dependent apoptosis in human cancer cells. Biochimie 2011, 93, 1065-1075. [CrossRef]

91. Leal, A.S.; Wang, R.; Salvador, J.A.; Jing, Y. Synthesis of novel heterocyclic oleanolic acid derivatives with improved antiproliferative activity in solid tumor cells. Org. Biomol. Chem. 2013, 11, 1726-1738. [CrossRef]

92. Han, Y.; Dong, W.; Guo, Q.; Li, X.; Huang, L. The importance of indole and azaindole scaffold in the development of antitumor agents. Eur. J. Med. Chem. 2020, 112506. [CrossRef]

93. Khusnutdinova, E.F.; Petrova, A.V.; Apryshko, G.N.; Kukovinets, O.S.; Kazakova, O.B. Synthesis and cytotoxicity of indole derivatives of betulin, erythrodiol, and uvaol. Russ. J. Bioorg. Chem. 2018, 44, 322-329. [CrossRef]

94. Khusnutdinova, E.F.; Petrova, A.V.; Kukovinets, O.S.; Kazakova, O.B. Synthesis and cytotoxicity of 28-N-propargylaminoalkylated 2,3-indolotriterpenic acids. Nat. Prod. Commun. 2018, 13, 1934578X1801300603. [CrossRef]

95. Tang, K.; Huang, J.; Pan, J.; Zhang, X.; Lu, W. Design, synthesis and biological evaluation of C (6)-indole celastrol derivatives as potential antitumor agents. RSC Adv. 2015, 5, 19620-19623. [CrossRef]

96. Fan, H.; Geng, L.; Yang, F.; Dong, X.; He, D.; Zhang, Y. Ursolic acid derivative induces apoptosis in glioma cells through down-regulation of cAMP. Eur. J. Med. Chem. 2019, 176, 61-67. [CrossRef] [PubMed]

97. Walayat, K.; Mohsin, N.U.A.; Aslam, S.; Ahmad, M. An insight into the therapeutic potential of piperazine-based anticancer agents. Turkish J. Chem. 2019, 43, 1-23. [CrossRef]

98. Rathi, A.K.; Syed, R.; Shin, H.S.; Patel, R.V. Piperazine derivatives for therapeutic use: A patent review (2010-present). Expert Opin. Ther. Pat. 2016, 26, 777-797. [CrossRef]

99. Zhao, C.H.; Zhang, C.L.; Shi, J.J.; Hou, X.Y.; Feng, B.; Zhao, L.X. Design, synthesis, and biofunctional evaluation of novel pentacyclic triterpenes bearing O-[4-(1-piperazinyl)-4-oxo-butyryl moiety as antiproliferative agents. Bioorg. Med. Chem. Lett. 2015, 25, 4500-4504. [CrossRef]

100. Yamansarov, E.Y.; Osterman, I.A.; Komarova, E.S.; Skvortsov, D.A.; Saltikova, I.V.; Majouga, A.G.; Ivanenkov, Y.A.; Giniyatullina, G.V.; Kazakova, O.B.; Baikova, I.P. Synthesis and cytotoxicity of a-azepanobetulinic acid N-methyl-piperazinylamide. Nat. Prod. Commun. 2019, 14. [CrossRef]

101. Hua, S.X.; Huang, R.Z.; Ye, M.Y.; Pan, Y.M.; Yao, G.Y.; Zhang, Y.; Wang, H.S. Design, synthesis and in vitro evaluation of novel ursolic acid derivatives as potential anticancer agents. Eur. J. Med. Chem. 2015, 95, 435-452. [CrossRef]

102. Liu, M.C.; Yang, S.J.; Jin, L.H.; Hu, D.Y.; Xue, W.; Song, B.A.; Yang, S. Synthesis and cytotoxicity of novel ursolic acid derivatives containing an acyl piperazine moiety. Eur. J. Med. Chem. 2012, 58, 128-135. [CrossRef] 
103. Wang, W.; Lei, L.; Liu, Z.; Wang, H.; Meng, Q. Design, synthesis, and biological evaluation of novel nitrogen heterocycle-containing ursolic acid analogs as antitumor agents. Molecules 2019, 24, 877. [CrossRef] [PubMed]

104. Kahnt, M.; Hoenke, S.; Fischer, L.; Al-Harrasi, A.; Csuk, R. Synthesis and cytotoxicity evaluation of DOTA-conjugates of ursolic acid. Molecules 2019, 24, 2254. [CrossRef] [PubMed]

105. Choudhary, S.; Singh, P.K.; Verma, H.; Singh, H.; Silakari, O. Success stories of natural product-based hybrid molecules for multi-factorial diseases. Eur. J. Med. Chem. 2018, 151, 62-97. [CrossRef] [PubMed]

106. Brandão, G.C.; Missias, F.C.R.; Arantes, L.M.; Soares, L.F.; Roy, K.K.; Doerksen, R.J.; de Oliveira, A.B.; Pereira, G.R. Antimalarial naphthoquinones. Synthesis via click chemistry, in vitro activity, docking to PfDHODH and SAR of lapachol-based compounds. Eur. J. Med. Chem. 2018, 145, 191-205. [CrossRef] [PubMed]

107. Sommerwerk, S.; Heller, L.; Kuhfs, J.; Csuk, R. Selective killing of cancer cells with triterpenoic acid amides-The substantial role of an aromatic moiety alignment. Eur. J. Med. Chem. 2016, 122, 452-464. [CrossRef]

108. Hoenke, S.; Heise, N.V.; Kahnt, M.; Deigner, H.P.; Csuk, R. Betulinic acid derived amides are highly cytotoxic, apoptotic and selective. Eur. J. Med. Chem. 2020, 207, 112815. [CrossRef] [PubMed]

109. Kadela-Tomanek, M.; Bębenek, E.; Chrobak, E.; Marciniec, K.; Latocha, M.; Kuśmierz, D.; Jastrzębska, M.; Boryczka, S. Betulin-1, 4-quinone hybrids: Synthesis, anticancer activity and molecular docking study with NQO1 enzyme. Eur. J. Med. Chem. 2019, 177, 302-315. [CrossRef] 